\title{
Cellular Innate Immunity against PRRSV and Swine Influenza Viruses
}

\author{
Elisa Crisci ${ }^{1,2}$, Lorenzo Fraile $^{3}$ (D) and Maria Montoya ${ }^{4, * \mathbb{D}}$ \\ 1 Department of Population Health and Pathobiology, College of Veterinary Medicine, \\ North Carolina State University, Raleigh, NC 27607, USA; ecrisci@ncsu.edu \\ 2 Comparative Medicine Institute, North Carolina State University, Raleigh, NC 27607, USA \\ 3 Universitat de Lleida, 25198 Lleida, Spain; lorenzo.fraile@ca.udl.cat \\ 4 Centro de Investigaciones Biológicas, Consejo Superior de Investigaciones Científicas (CIB-CSIC), \\ 28040 Madrid, Spain \\ * Correspondence: maria.montoya@cib.csic.es; Tel.: +34-935814562; Fax: +34-935814490
}

Received: 12 December 2018; Accepted: 27 February 2019; Published: 11 March 2019

\begin{abstract}
Porcine respiratory disease complex (PRDC) is a polymicrobial syndrome that results from a combination of infectious agents, such as environmental stressors, population size, management strategies, age, and genetics. PRDC results in reduced performance as well as increased mortality rates and production costs in the pig industry worldwide. This review focuses on the interactions of two enveloped RNA viruses-porcine reproductive and respiratory syndrome virus (PRRSV) and swine influenza virus (SwIV) - as major etiological agents that contribute to PRDC within the porcine cellular innate immunity during infection. The innate immune system of the porcine lung includes alveolar and parenchymal/interstitial macrophages, neutrophils (PMN), conventional dendritic cells (DC) and plasmacytoid DC, natural killer cells, and $\gamma \delta \mathrm{T}$ cells, thus the in vitro and in vivo interactions between those cells and PRRSV and SwIV are reviewed. Likewise, the few studies regarding PRRSV-SwIV co-infection are illustrated together with the different modulation mechanisms that are induced by the two viruses. Alterations in responses by natural killer (NK), PMN, or $\gamma \delta$ T cells have not received much attention within the scientific community as their counterpart antigen-presenting cells and there are numerous gaps in the knowledge regarding the role of those cells in both infections. This review will help in paving the way for future directions in PRRSV and SwIV research and enhancing the understanding of the innate mechanisms that are involved during infection with these viruses.
\end{abstract}

Keywords: pig; innate immunity; PRRSV; swine influenza virus

\section{The Porcine Respiratory Complex: General Features and PRRSV and SwIV Involvement}

The term porcine respiratory disease complex (PRDC) was used in the past to describe the pneumonia of multiple etiologies that cause clinical disease with negative consequences on productive parameters during the finishing process. Nowadays, the term delineates a more general term describing a polymicrobial syndrome that results from a combination of infectious agents, environmental stressors, population size, management strategies, age, and genetics that causes reduced performance, together with increase mortality rates and production costs in the pig industry worldwide. The etiology of the PRDC has been in continuous progression due to pathogen evolution as well as in management and stressor changes in pig farming [1-3].

The respiratory disease complex is the consequence of impairment of the normal respiratory immune system due to pathogens that are able to harm these defenses and establish infection on their own. Those microorganisms are normally considered to be the primary etiological agents and 
only, subsequently, other opportunistic agents appear in order to take advantage of the virulence mechanisms of the primary ones [1-3].

Porcine primary agents include viruses, like porcine reproductive and respiratory syndrome virus (PRRSV), swine influenza virus (SwIV), porcine circovirus type 2, pseudorabies virus, and bacteria, like Mycoplasma hyopneumoniae, Bordetella bronchiseptica, and Actinobacillus pleuropneumoniae [4-6]. Minor viral pathogens that are associated with respiratory implication are also the result of paramyxoviridae family viruses (such as porcine rubulavirus and Nipah virus), porcine cytomegalovirus, porcine respiratory coronavirus, porcine parvovirus, and porcine torque tenovirus [7]. Pasteurella multocida, Haemophilus parasuis, Streptococcus suis, and Trueperella pyogenes are other common minor bacterial agents that are only linked with respiratory manifestations [8], although this latter one can also cause primary respiratory disease, likely through a blood-borne route [1-3].

In this review, we will focus, in particular, on two enveloped RNA viruses, PRRSV and SwIV, as major etiological agents that contribute to PRDC and on the recent discoveries in porcine cellular innate immunity during PRRSV and/or SwIV infection.

\subsection{Porcine Reproductive and Respiratory Syndrome Virus}

Porcine reproductive and respiratory syndrome virus (PRRSV) is a member of the family Arteriviridae, which also includes the simian hemorrhagic fever virus (SHFV) and equine arterivirus (EAV). It is an enveloped, positive-stranded RNA virus and the viral genome, packed by nucleocapsid proteins, contains 11 known open reading frames (ORFs). The replicase gene consists in ORFs $1 \mathrm{a}$ and $1 \mathrm{~b}$ regions that encode two large nonstructural polyproteins, pp1a and pp1ab, which are processed into at least 14 non-structural proteins (nsps). The other genes, ORF2-7, encode for four membrane-associated glycoproteins (GP2a, GP3, GP4, and GP5), three unglycosylated membrane proteins (E, ORF5a, and $\mathrm{M})$, and a nucleaocapsid protein $(\mathrm{N})[9,10]$. PRRSV exists as two species, type 1 (European origin, PRRSV-1) and type 2 (North American origin, PRRSV-2), which share only 55-70\% nucleotide identity, but its replication and recombination properties have led to the extraordinary phenotype and genotype diversity worldwide [11,12].

Swine are the only natural host of PRRSV and the virus has a very restricted tropism for cell of the monocytic lineage. The fully differentiated porcine alveolar macrophages have been considered as the cell target for PRRSV [13], but more recently parenchyma macrophage-like/pulmonary intravascular macrophages (PIM) have been described as also supporting PRRSV replication [14].

On the macrophages, CD163 has been determined to be the major receptor that mediates viral internalization and disassembly. CD169 (sialoadhesin or siglec-1) can also serve as a virus receptor via interaction with GP5/M ectodomains, but it is considered to be not essential for attachment and/or internalization. Other cellular receptors are heparan sulphate, vimentin, CD151, DC-SIGN (CD209), and, lately, siglec-10, has been shown to be involved in the entry process of PRRSV [15]. Recently, CD163 has been edited in pig zygotes using CRISPR/Cas9, so as to remove the viral interaction domain while maintaining protein expression and biological function. These "edited" pigs were resistant to PRRSV-1 as well as PRRSV-2 infection in vitro. Moreover, when these animals were challenged with a highly virulent PRRSV-1 subtype 2 strain, the edited pigs showed no signs of infection or viremia or antibody response indicative of a productive infection, which is in contrast to the wild-type control group. Thus, "edited" pigs are fully resistant to infection by PRRSV and confirm CD163 as major PRRSV receptor [16,17].

\subsection{Swine Influenza Virus}

Influenza viruses (IVs) are enveloped, single stranded RNA viruses belonging to the family Orthomyxoviridae. This family comprises different genera; in particular A, B, and C. Influenza A viruses are further classified into subtypes based on the antigenicity of their hemagglutinin (HA) and neuraminidase (NA) molecules. Currently, 18 HA (H1-H18) and 11 NA subtypes (N1-N11) have been described [18,19]. 
Influenza A and B viruses possess the segmented genome of eight single-stranded negative-sense RNA molecules that typically encode 11 or 12 viral proteins [20]. The viral envelope consists of a lipid bilayer that contains transmembrane proteins on the outside and matrix protein (M1) on the inside. The lipids that compose the envelope derived from the host plasma membrane and are selectively enriched in cholesterol and glycosphingolipids. The three transmembrane envelope proteins-HA, NA, and M2 (ion channel) - are anchored in the lipid bilayer of the viral envelope. HA is the major envelope protein forming the spikes [21]. HA provides the receptor-binding site and elicits neutralizing antibodies. It binds to a host cell receptor that contains terminal $\alpha-2,6$-linked or $\alpha$-2,3-linked sialic acid $(\alpha-2,6-S A$ or $\alpha-2,3-S A)$ moieties.

IVs infect different animal species and pigs (Sus scrofa) and they are one of the natural hosts of these viruses. Swine influenza is a highly important respiratory swine disease and the main causative viruses are type A IVs H1N1, H1N2, and H3N2 subtypes [22], which are antigenically related to human IVs. Pigs are susceptible to infection with avian and human IVs [23,24] and they are supposed to play an important role in human influenza ecology. In fact, genetic reassortment between human and/or avian and/or swine IVs can occur. The potential to generate novel IVs has resulted in swine being labelled "mixing vessels". There are three facts that support the mixing vessel hypothesis: (1) swine are susceptible to avian and human viruses; (2) reassortment of swine/avian/human viruses occurs in pigs; and, (3) pigs can transmit reassortant IVs to humans [25]. Infection in pigs with IVs results in an acute respiratory infection that resolves within a week if no other complications are present with the activation of the immune system [26].

\section{Porcine Innate Immune System}

\subsection{Dendritic Cells}

Dendritic cells (DC) are key antigen presenting cells that prime naïve T cells and drive the adaptive immune response. They are very effective in sensing viruses through a wide range of surface, cytosolic, and endosomal receptors, and Toll-like receptors (TLR) are crucial DC pattern recognition receptors between those.

Summerfield and McCullough firstly reviewed the Porcine DC family in 2009. In vitro, DC can be divided in monocyte-derived DC (moDC) and bone marrow derived DC (BMDC, considered conventional DC). In vivo, besides moDC and the conventional DC (cDC), we also have the plasmacytoid DC ( $\mathrm{pDC}$ ) and both are located in the blood and the mucosa of the different biological tracts.

In vitro, moDC and BMDC generally express CD172a, CD1, CD14 low/+, CD16, SLAII +/hi, and CD80/86, while blood cDC normally present CD14-, low CD172a, and variable CD1 and CD16 expressions (Table 1). In all cases, CDC are CD4- and they predominantly express TRL2, TLR4, and TLR3 and TLR8. On the other side, pDC are generally CD172a low / - , CD123+, CD135+, CD1+/-, CD16+/-, CD4+, SLAII+, CD80/86low, and CD14- (Table 1), and they predominantly express TLR7 and TLR9 $[27,28]$. moDC have been extensively used in the last decade as an in vitro strategy to study the effect of different viruses on pivotal cells driving adaptive immunity. Generally, moDC have been generated after PBMC isolation, CD14+ selection, or PBMC plastic culture to isolate adherent monocytes. Using different amounts of GMCSF and IL4, moDC were harvested after 5-7 days of culture and immature or mature moDC were used for PRRSV infection [29].

In vivo, cDC have been mainly studied from peripheral blood mononuclear cells (PBMC) following different sorting strategies, given the low percentage of these cells in a normal pig (between $0.1-1 \%)$. Their phenotype is as stated above, but other markers have been used to define different subsets as cDC1 or cDC2 using CD1, CADM1, or XCR1 [30]. Mucosal DC present a similar basic phenotype to $\mathrm{CDC}$ and $\mathrm{pDC}$, but the surface marker expressions showed different profiles, depending on the biological tract considered. Pulmonary and tracheal DC have been characterized into three distinctive populations according to their phenotype and functional capacities: cDC1, cDC2, and 
inflammatory DC [31]. Given the respiratory tropism of PRRSV and SwIV, in this review we will only focus on results that were obtained using in vitro derived-DC and primary DC present in the respiratory tract.

Table 1. Porcine innate immune cells phenotype and porcine reproductive and respiratory syndrome virus (PRRSV) and swine influenza viruses (SwIV) susceptibility.

\begin{tabular}{|c|c|c|c|}
\hline $\begin{array}{l}\text { Porcine Innate } \\
\text { Immune Cells }\end{array}$ & Phenotype & $\begin{array}{l}\text { PRRSV } \\
\text { Susceptibility }\end{array}$ & $\begin{array}{l}\text { SwIV } \\
\text { Susceptibility }\end{array}$ \\
\hline $\begin{array}{l}\text { MoDC } \\
\text { BMDC } \\
\text { cDC }\end{array}$ & $\begin{array}{l}\text { In vitro moDC and BMDC } \\
\text { SLAII+, SLAI+, CD80/86low/+, CD16+, } \\
\text { CD14low, CD172a+, CD1+ } \\
\text { In vivo tracheal cDC1 and cDC2 } \\
\text { (Resendiz et al. 2018) } \\
\text { cDC1, CD163-, SLAIIhi, CADM1+, CD172a -, } \\
\text { FLT3+, XCR1+ } \\
\text { cDC2 CD163-, SLAIIhi, CADM1hi, CD172a+, } \\
\text { FLT3+, FceR1 } \alpha+ \\
\text { In vivo lung DC (density gradient separation } \\
\text { and CD11c+) (Loving et al. 2007) } \\
\text { SLAI+, CD80/86+, SLAII+, and CD16+, } \\
\text { CD14low, CD172a+, CD1+ } \\
\text { In vivo lung DC (Proll et al. 2017) } \\
\text { CD11c+, CD86+, CD80+, CD40+ } \\
\text { In vivo lung CDC1, CDC2, moDC } \\
\text { (Bordet et al. 2018) } \\
\text { cDC1 SLAIIhi, CD163-, CD172a-/low, CD11c+, } \\
\text { CadM1+ XCR1+ } \\
\text { cDC2 SLAIIhi, CD163-, CD172a+, CD11c+, } \\
\text { Cadm1+, CD1+ FceRI } \alpha+ \\
\text { moDC SLAIIhi, CD163low, CD172a+, CD11chi }\end{array}$ & $\begin{array}{l}\text { No } \\
\text { Yes }\end{array}$ & $\begin{array}{l}\text { N/A } \\
\text { N/A } \\
\mathrm{N} / \mathrm{A} \\
\text { In vivo moDC increase in } \\
\text { number during SwIV } \\
\text { (Maisonnasse et al. 2016) }\end{array}$ \\
\hline $\mathrm{pDC}$ & $\begin{array}{l}\text { In vivo } \\
\text { CD4+/hi, CD172alow/+, CD1a+, CD11a+, } \\
\text { CD11b-, CD11c-, CD16+, CD18+, CD29+, } \\
\text { CD44+, SLAII+, CD123+, CD135+, CD14- }\end{array}$ & No & $\mathrm{N} / \mathrm{A}$ \\
\hline Macrophages & $\begin{array}{l}\text { In vivo lung alveolar M } \Phi \\
\text { CD163+, CD169+, SWC9+(CD203a), CD172a+, } \\
\text { CD14+, CD16+, and SLAII+ } \\
\text { In vivo AM-like/PIM M } \Phi \\
\text { CD163+, CD169+, CD172a+, CD14+, CD16+, } \\
\text { and SLAII+ }\end{array}$ & $\begin{array}{l}\text { Yes } \\
\text { Yes }\end{array}$ & $\begin{array}{l}\text { In vitro transformed 3D/ } 4 \text { cells } \\
\text { infected by H1N1 pdm } 2009 \\
\text { (Gao et al. 2012) }\end{array}$ \\
\hline Neutrophils & In vivo SWC1+ or CD21+, SWC8+ & No & Not clear \\
\hline NK and $\gamma \delta$ T cells & $\begin{array}{l}\text { In vivo } \mathrm{NK} \\
\text { perforin+, CD2+, CD8 } \alpha+, \mathrm{NKp} 46+, \mathrm{CD} 8 \beta-, \\
\mathrm{CD} 11 \mathrm{~b}+, \mathrm{CD} 16+, \mathrm{CD} 3-, \mathrm{CD} 4-, \mathrm{CD} 5-/ \text { low, CD6- } \\
\text { In vivo } \gamma \delta \mathrm{T} \text { cells divided in } 3 \text { subsets: } \\
\mathrm{TCR} \gamma \delta \text { hi, CD2-CD8-, } \\
\text { TCR } \gamma \delta \text { med CD2+CD8- and TCR } \gamma \delta \text { med } \\
\mathrm{CD} 2+\mathrm{CD} 8+\end{array}$ & No & No \\
\hline
\end{tabular}

\subsection{Macrophages}

Some macrophage $(\mathrm{M} \Phi)$ precursors differentiate in the bone marrow into monocytes, which enter the blood stream. They then migrate to the different tissues, where they further differentiate into specific macrophages. They constitute the so-called mononuclear phagocyte system (MPS). M $\Phi$ are considered to be antigen presenting cells and they have important regulatory and effector functions in the specific immune response and in the maintenance of tissue homeostasis [32]. 
Two M $\Phi$ subsets are recognized, being referred to as M1 and M2, which result from classical or alternative activation, respectively. Classical (M1) activation of $\mathrm{M} \Phi$ requires two signals, namely IFN $\gamma$ and TLR ligation, and they can be generated in vitro using IFN $\gamma$ and LPS. M1 macrophages are able to kill intracellular pathogens infecting them, and then produce pro-inflammatory cytokines, including IL1 $\beta, \mathrm{TNF} \alpha$, IL6, IL12, and IL23. Alternative (M2) activation of macrophages occurs via IL4 or IL13 and reflects increased mannose receptor expression (CD206) and are distinct from M1 MФs by their limited killing ability. M2 M $\Phi$ s are associated with wound repair, producing components for extracellular matrix synthesis [33-35].

Porcine macrophages express CD163, a scavenger receptor, CD169 (also known as sialoadhesin or siglec-1), and SWC9/CD203a (found in lung macrophages). Additionally, the other monocytic lineage markers are CD172a, CD14, CD16, and SLAII. They mainly express TLR2, TLR4, and TLR3, 7, 8 [32]. Porcine lung macrophages can be divided based on the microenvironment within the lung: alveolar macrophages (AM), pulmonary intravascular macrophages (PIM) and interstitial macrophages (IM) [36,37]. Swine PIM and IM have been recently included in the so-called AM-like macrophages [14].

\subsection{Neutrophils}

Neutrophils or polymorphonuclear neutrophils (PMNs) are the first line of specialized innate phagocytes during acute pathogens infection. They are an important component in the simulation of the inflammatory response, in some cases, causing detrimental collateral damage and killing pathogens through phagocytosis, degranulation, and extracellular traps (NETs) formation. During the NETs formation they release antimicrobial peptides, such as several neutrophil serine proteases (NSPs). Swine PMNs are SWC1+ or CD21+ and SWC8+ display the same morphology as those of humans, but are a smaller size, with lower granularity and higher activation threshold [27,38].

\subsection{Natural Killer Cells}

Circulating porcine lymphocyte population features are unusual when compared with human and mice populations, since they present abundant natural killer (NK) and $\gamma \delta \mathrm{T}$ cells [39,40]. NKT cells are not included in this section.

NK cells are a component of the innate immune system with the ability to spontaneously attack pathogen-infected and malignant body cells as well as to produce regulatory cytokines, such as IFN $\gamma$. They lyse virus-infected target cells and up regulate effector/activation molecules, like perforin and CD25. In some cases of activation, an additional SLAII DR expression was described. Porcine NK cells have been identified by a complex phenotype of perforin+, CD2+, CD8 $\alpha+$, CD8 $\beta-$, CD11b+, CD16+, CD3-, CD4-, CD5-,CD6- [39,41-43], and for the expression of NKp46, an evolutionary conserved mammal receptor that belongs to the family of natural cytotoxicity receptors (NCRs). Studies considering NKp46 expression in pigs defined three distinct NK-cell subsets: NKp46-, NKp46+, and NKp46hi CD3- lymphocytes that display the phenotypic and functional properties of NK cells $[42,43]$. A distinct population of CD3+NKp46+ cells could also be identified where the majority of CD3+NKp46+ cells express CD8 $\alpha \beta$ heterodimer, comparable to porcine cytolytic T cells, while a minor subset belongs to the TCR $\gamma \delta+$ T cells. Nonetheless, the CD3+NKp46+ cells express NK-associated molecules, such as perforin, CD16, NKp30, and NKp44. Functionally, they respond to in vitro stimulation in a NK-like manner and they have the capacity of spontaneous cytolytic activity. Degranulation could be induced in CD3+NKp46+ lymphocytes by receptor triggering of both NKp46 and CD3 [42,43].

\section{5. $\gamma \delta$ T Cells}

Swine, together with ruminants and birds, belongs to the group of $\gamma \delta$ high species in which $\gamma \delta$ $\mathrm{T}$ cells are not preferentially limited to epithelia and they may account for $25-85 \%$, depending on the age of all circulating peripheral blood lymphocytes (PBL). T cells of $\gamma \delta$ lineage are evolutionary conserved cells that develop in the thymus similarly to $\alpha \beta$ T cells, but they do not need any selection 
for pre-antigen receptors and therefore mature faster than $\alpha \beta$ T cells. $\gamma \delta$ T share many features with $\alpha \beta \mathrm{T}$ cells, such as potent cytotoxic activity, regulatory functions, including the ability to induce maturation of dendritic cell, the capacity to produce a variety of cytokines, and they also generate and retain immunologic memory. $\gamma \delta \mathrm{T}$ respond rapidly to infection and they are probably involved mainly in mucosal immunity. They can act as antigen-presenting cells and their TCR recognizes a broad spectrum of unprocessed or non-peptide antigens without any requirement for MHC co-signalization. Due to their nature, the $\gamma \delta \mathrm{T}$ cells are often categorized as unconventional $\mathrm{T}$ cells and probably form a unique link between innate and adaptive immune responses [40,41,44,45].

Traditionally, $\gamma \delta \mathrm{T}$ cells in swine are subdivided into three subsets based on their expression of $\mathrm{CD} 2$ and $\mathrm{CD} 8$ and they include CD2-CD8-,CD2+CD8-, and CD2+CD8+ cells. These individual subsets differ in their homing characteristic and cytotoxic activities. Porcine $\gamma \delta \mathrm{T}$ cells have two levels of TCR $\gamma \delta$ expression: TCR $\gamma \delta$ med cells are mostly CD3+CD2+CD8 - and CD2+CD8+, whereas $\mathrm{TCR} \gamma \delta$ hi cells are highly enriched for CD2-CD8-. Finally, many $\gamma \delta \mathrm{T}$ cells can constitutively express CD25 and MHCII and the frequency of $\gamma \delta$ T cells that are positive for CD25, CD11b, SWC1, and SWC7 can be increased by stimulation $[40,41,44,45]$.

\section{Innate Cellular Immune Responses Triggered by PRRSV}

PRRSV is capable of causing reproductive and respiratory disease, and PRRS has an estimated annual cost to the swine industry of 664 million dollars in the United States of America (USA) [46]. The innate immune system is the first line of defense against any infection and, in particular, for PRRSV, lung $M \Phi$, and DC is critical in the prevention of viral invasion in the blood circulation and inducing protective adaptive immunity.

Generally, PRRSV elicits poor innate responses that are associated with incomplete viral clearance in most of the pigs, depending on their age and immune status [9,10]. Infection with certain PRRSV strains induces significant suppression of NK cytotoxic activity and the quantity of the innate cytokines secreted in PRRSV-infected pigs is significantly lower than other viral infections and it is strain dependent $[9,10,47]$. PRRSV infection is generally a poor inducer of type I IFNs and its level remains low throughout the course of infection, as noted in pigs that were infected with many field isolates. Thus, to establish clinical disease in pigs, PRRSV modulates the host innate immunity through the dysregulation of NK cell function and IFNs production [34]. A recent study has provided new insight by showing how new virulent strains can differently modulate the inflammatory response toward a Th1 response in the lung [48].

\subsection{Macrophages}

Porcine alveolar macrophages (PAMs) have been extensively studied during PRRSV infection as the primary cell target of the virus. In this section, we will only review the latest discoveries while focusing on recent advances that were achieved with genomics approaches in primary PAMs and in the new insights on lung interstitial macrophages. When compared to porcine AM, PIM are equally permissive to PRRSV infection [14,37]. Almost two decades ago, PRRSV-2 antigens and nucleic acids have been demonstrated in PIM both in vitro and in vivo [37]. Examination of cultured PIM infected with PRRSV revealed the accumulation of viral particles in vesicles and the infection induces either PIM apoptosis or cell lysis. The PIM in vitro bactericidal activity is decreased as the in vivo phagocytic activity, measured by pulmonary copper clearance in PRRSV-infected pigs [37]. Recently, AM-like cells have been defined as macrophages phagocytosing blood-borne particles, which is in agreement with the PIM identity [14]. PIM were described as the major producer of PRRSV-1 Lena virus and their infection correlated better with viremia in vivo than AM infection. Thus, AM-like cells were as permissive as AM to PRRSV infection in vitro and in vivo, and PIM-expressed genes were characteristic of an embryonic monocyte-derived macrophage population [14].

Macrophages that were infected with PRRSV are functionally compromised in many ways, including cytokine production [34,49] and polarization [50]. PRRSV-2 prototype virus VR-2332 is 
one of the most studied strains, and the reactomes of infected PAM have been described at different time points. 573 differentially expressed genes (DEGs) were assigned into six biological systems, 60 functional categories and 504 pathways. Cell growth and death, transcription processes, signal transductions, energy metabolism, immune system, and infectious diseases formed the major reactomes of PAMs responding to PRRSV infection [51].

Only recently, data using different PRRSV-2 isolates suggests that macrophages polarization modulates PRRSV infection. Anti-viral cytokine expression was significantly higher in M1 macrophages than in M2 macrophages or non-polarized controls and both highly pathogenic (HP)(HuN4) and classic PRRSV (CH-1a) replication was significantly impaired in M1 PAMs [50]. Additionally, in HP PRRSV PAM infection (JXwn06), genes that are involved in IFN-related signaling pathways, pro-inflammatory cytokines and chemokines, phagocytosis, and antigen presentation and processing were significantly downregulated, indicating the aberrant function of PAM during the infection [52]. In particular, during early HP infection, the IFN $\beta$ downregulation seems to be mediated by a post-transcriptional inhibition through cellular miRNAs upregulation. This inhibition is stronger in HP when compared to a low pathogenic (LP) strain [53]. Additionally, lncRNAs have been reported during PRRSV and, in particular, 299 novel lncRNAs were differentially expressed after 12-24 hpi. All of the lncRNAs were enriched in pathways related to viral infection and immune response, particularly lncRNA TCONS_00054158 was adjacent to the TRAIL gene that was involved in apoptosis induction [54]. Moreover, during early infection, PRRSV-2 has been reported to induce both IL1 $\beta$ mRNA expression and secretion in a time- and dose-dependent manner, as mediated by the TLR4/MyD88 pathway and by the NLRP3 pathway $[55,56]$. The inhibitory effect appeared only in the late infection, where levels of pro-IL1 $\beta$ and procaspase- 1 mRNA and the mature IL1 $\beta$ protein decreased to mock level. An IL1 $\beta$ antagonist, nsp11, and its endoribonuclease activity, encoded by the virus to limit antiviral reponses, mediated the effected [55].

Transcriptome differences between breeds during high pathogenic PRRSV infection have also been highlighted. Previous studies showed that Large White (LW) breed are more susceptible to PRRSV than Chinese breed Tongcheng (TC). At 7 dpi, PRRSV-infected PAM from TC showed 1257 differentially expressed genes (DEGs) involved in hepatic fibrosis/hepatic stellate cell activation, phospholipase C, granulocyte adhesion, and diapedesis pathways. In particular, 549 specific DEGs, including VAV2, BCL2, and BAX, were enriched in activation of leukocyte extravasation and suppression of apoptosis. On the other hand, 898 specific DEGs were defined in LW pigs, including genes that are involved in the suppression of G $\alpha$ q and PI3K-AKT signaling. In this study, the authors proposed that in TC, the promotion of extravasation, migration of leukocyte and suppression of apoptosis constitute the defense mechanism against PRRSV [57].

In summary, an aberrant antiviral response is induced in PAMs by PRRSV infection, suppressing IFN type I induction, and M1 polarization impair viral replication (Figures 1 and 2). 


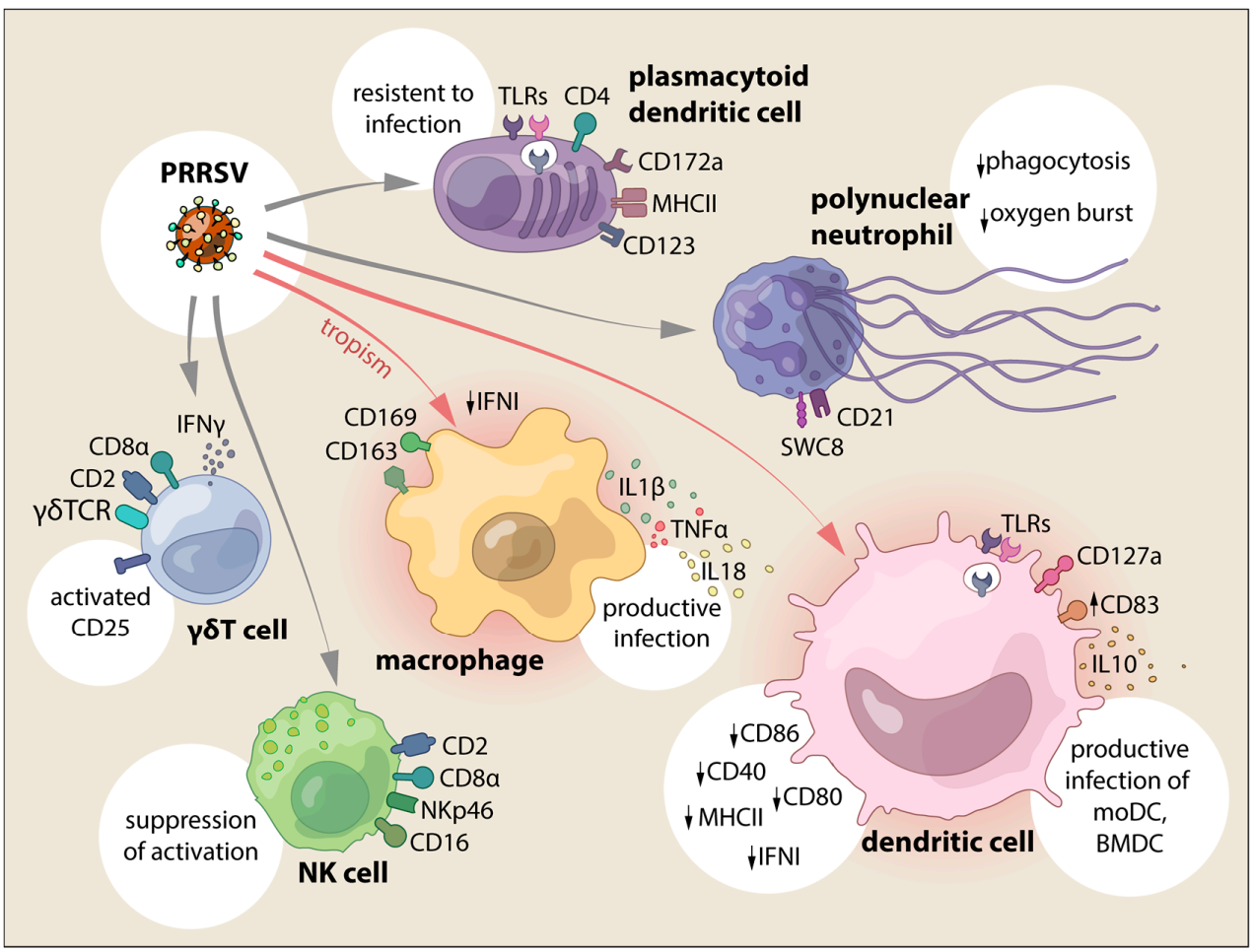

Figure 1. PRRSV interaction with cells from the innate immune system and the main effects reported.

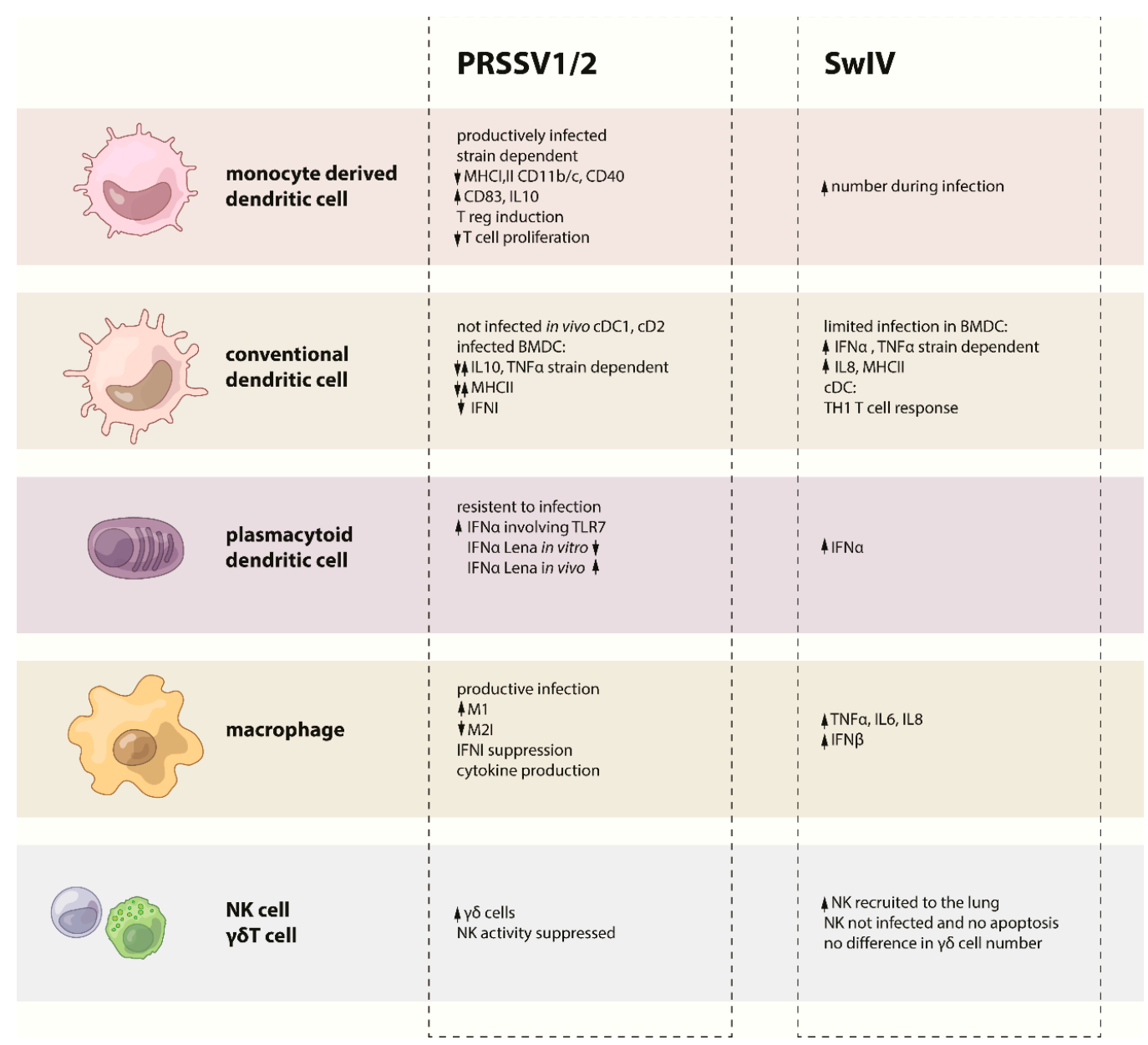

Figure 2. Summary on the PRRSV or SwIV effects on each cell from the innate immune system. 


\subsection{Dendritic Cells}

The PRRSV infection of DC has been controversial in the last decade, which is mainly due to the different in vitro DC generation systems and the intrinsic variability of the virus. In this section, we will summarize the most common DC systems that are used when infecting with PRRSV, the most relevant discoveries, and the new knowledge in the field.

\subsubsection{Conventional DC and Monocyte-Derived DC}

Several PRRSV-1 and 2 viruses have been used when infecting DC, showing how the different outcomes are also related to the different strains and multiplicity of infection (MOI) used in the in vitro system. All in all, there is a clear agreement in the scientific community regarding the ability of PRRSV to productively infect moDC in vitro, despite the kinetics divergences that are related to the different MOI and time employed [58-63] and the variance between immature and mature moDC [64] or the proliferation levels of certain PRRSV strain [65].

Inconsistent data regarding PRRSV infection of other DC subsets are noticeable when primary lung and tracheal DC are considered. In fact, a recent publication [66] using primary lung DC, which was generated with enzymatic treatment and with an unclear DC phenotype (Table 1), showed that PRRSV-1 Lelystad (LV) virus was able to infect lung DC more efficiently in Duroc than in the Pietrain breed. On the other side, starting with Loving et al. in 2007 and finishing with recent results from both Resendiz et al. and Bordet et al. in 2018, it has been demonstrated that primary lung and tracheal DC are unable to support PRRSV-1 and 2 replication $[48,60,67]$. In Loving et al., lung DC were generated by density gradient separation and the selection of CD11c+ (Table 1), and PRRSV-2 NADC-8 did not infect them [60]. In Bordet et al., PRRSV-1 LV, Flanders13 and Lena did not infect, in vivo or in vitro, lung cDC1 cDC2 and moDC (only some residual infection in moDC) (Table 1) [48]. Following the same line of results, tracheal cDC1 and cDC2 (Table 1) were not susceptible to PRRSV-2 CIAD008 [67]. The scenario exhibits another layer of complexity when considering surface markers expression and $\mathrm{T}$ cell proliferation in studies where the outcomes differ when considering the PRRSV genotype, strains, and time points that are used in each experimental system.

PRRSV-2 generally reduced the antigen presenting functions of moDC by downregulating the expression of SLAI, SLAII, CD14, and CD11b/c, and by impairing their ability to activate both allogeneic and syngeneic T cell proliferation (PRRSV-2 SD-23983) [68]. Similar results were obtained with CNV-3 [69] and NVSL 97-7895 [59]. Liaoning et al. show unchanged SLAII but decreased SLAI, CD40, and CD80 [65], and other Chinese high and low pathogenic viruses that modulated CD83 [70,71]. DC-SIGN was not shown to be relevant during PRRSV-2 infection of moDC [61], and several PRRSV-2 isolates and commercial Ingelvac PRRS MLV vaccine showed no reduction in levels of T CD25+ or IFN $\gamma+$ or TNF $\alpha+$ cells that were cultured with infected moDC. In primary lung, DC PRRSV-2 infection does not modify CD80/86 expression but downregulates SLAI, whereas PRRSV infected lung DC conserved their normal $\mathrm{T}$ proliferation ability [60].

When PRRSV-1 was used in the experiments, some strains reduce SLAI and increase T proliferation without the production of IFN $\gamma$ in T cells [63] and others increase SLAII and CD80/86 in PRRSV N+ when compared with N- cells [62]. Prior infection moDC showed high expression levels of CD163 and low CD169 and replication was clearly restricted to a CD163+ CD169dim phenotype. There were no differences in the proliferation and frequency of Foxp3 after co-culturing with infected moDC [62]. PRRSV-1 LV, FL13, or Lena showed no differences in CD80/86, CD40, SLAII, SLAI expression on primary lung DC [48], and moDC showed different infection phenotype during dexamethasone and IL10 treatment [64].

Taking into account all of this variability, Rodríguez-Gómez et al. [62] considered the problem of the moDC markers expression, explaining the divergent outcomes to the use of different viral strains and virulence in the same genotype and to a suboptimal characterization of the experimental protocol that were used to generate moDC. 
The production of cytokines is the most diverse aspect of infection. Strains, time points, and in vitro conditions showed disparate results, from no mRNA IL10 change [58] to high IL10 production $[59,63,67,69]$ during PRRSV infection. Some strains do not promote the Th1 response $[48,68]$ (PRRSV-2), whereas others do [48,61,69]. Additionally, disparity is found when considering antiviral factors, on one side moDC and lung DC responded to PRRSV with increased transcription of IFN $\beta$, but there were no alterations in IFN $\alpha, M X$, or PKR transcripts [60], and on the other side PRRSV infection activated IFN $\alpha$, IFN $\beta$ transcription, but block of IFN $\alpha$ production [72]. In this last case, PRRSV-2 efficiently activated IFN $\alpha / \beta$ transcription in moDC in a time-dependent and transient manner, but little or no detectable IFN $\alpha$ was found in the supernatant and cell lysate of infected PRRSV DC. This effect was shown to be PI3K activation-dependent, but the post-transcriptional mechanism blocking IFN $\alpha$ production is still undefined [72].

An important and surprising finding was the role of Foxp3 Tregs during PRRSV infection. Hernendez group $[59,63,73]$ added several pieces of the puzzle, which introduced a new role of IL10 and Tregs during PRRSV infection. In particular, first using PRRSV-2 NVSL 97-7895 [59] and then other European strains $(2992,2993)$ [63], they showed increased IL10 production during infection. An important outcome was the lack of Treg induction by PRRSV-1 infected moDC [63]. On the other side, with PRRSV-2 NVSL 97-7895 and CIAD008, they showed the induction of Foxp3+ CD25+ cells in PRRSV infected DCs, reversible by IFN $\alpha$ treatment, and upregulation of TGF $\beta$ expression in co-culture, but not IL10. Additionally, the upregulation of Foxp3 mRNA and the suppressor activity of Tregs on PHA stimulated lymphocytes were shown [73].

Finally, more recent studies on the interaction between DC and PRRSV have been focused on intracellular pathways and transcriptome. Chen et al. showed the involvement of different viral proteins on CD83 expression. CD83 is induced and viral proteins (N, nsp1, nsp10) affect the CD83 promoter in a time and dose dependent manner via the NFkB and Sp1 signaling pathways. PRRSV stimulates the expression of Sp1 and NFkB mRNA and NSp1 $\alpha$ impairs moDC function releasing soluble CD83. PRRSV infection inhibits TAP1 and ERp57 expression (MHC complex proteins) by the induction of soluble CD83 and an impaired ability to stimulate T proliferation [70,71].

On the other hand, Proll et al. performed the first Gene Ontology (GO) analysis to determine the immune response to PRRSV LV infection in lung DC of two different breeds (Duroc and Pietrain). Although the phenotyping of DC was not very specific and lung DC probably included a macrophage component, the transcriptome profile showed breed specific differences in response to the infection. They identified key clusters and pathways as well as specific genes (SEC61ß, SLA7) that play important roles in animal health. Finally, the up regulation of IL1 $\beta$ in Duroc could explain the better immune response of Duroc when compared to Pietrain [66].

\subsubsection{Bone Marrow Derived DC}

Mateu's group performed the first study in bone marrow derived DC (BMDC), which extensively used BMDC to study PRRSV pathogenesis. They tested 39 European isolates that were able to induce different patterns of IL10 and TNF $\alpha$ production and different surface markers regulation. BMDC were productively infected by PRRSV isolated and MHCII upregulation was observed in selected PRRSV-1 strains [74]. Between the PRRSV-1 strains, high pathogenic Lena, together with Belgium A and Lelystad, reflected a different pattern. Lena showed a higher replication rate and apoptosis in BMDC when compared with other PRRSV-1 strains (Lelystad and Belgium A), but controversially it induced SLAII down regulation together with CD14, SWC3, and CD163 [75].

A most recent publication from Mateu's group had characterized, in more detail, the interaction between PRRSV-1 strains and BMDC [76] when PRRSV-1 replication and attachment in immature (iBMDC) and mature BMDC (mBMDC) was studied. Replication kinetics showed that titres in iBMDC were significantly higher than mBMDC by $24 \mathrm{hpi}$ and iBMDC were more efficient in the support of PRRSV-1 replication than mBMDC. iBMDC attachment by all of the strain was possible in cells that lack porcine CD163 or sialoadhesin (CD169) receptors or in cells with heparan sulfate (unspecific 
attachment receptor) removed. PRRSV-1 nucleocapsid could be observed in CD163- iBMDC and those cells were only infected when CD163low/hi cells were present, indicating that the susceptibility of CD163 - cells derived as result of the milieu that was created by CD163+ infected BMDC, by receptor-independent mechanisms or that some cells expressed CD163 at levels that were below the technical sensitivity [76].

This study, together with most recent ones $[64,77,78]$, questioned the notion of CD163 relevance during the infection. Nevertheless, the essential role of this receptor for viral uncoating and pathogenesis is still supported by the generation of genome edited pigs that lack the CD163 SRCR5 domain, which showed to be resistant to PRRSV infection [16,17].

As a whole, DC responses against PPRSV showed a general dysregulation of the IFN response, downregulation of activation and maturation markers with an induction of IL10 and Treg (Figures 1 and 2).

\subsubsection{Plasmacytoid DC}

Plasmacytoid dendritic cells (pDC) are the major source of type I IFNs and other inflammatory cytokines after exposure to viruses. Type I interferons are essential for direct antiviral activity and, despite pDC low frequency, they can produce around 100 times more IFN $\alpha$ than any other cell type and sense viruses in the absence of replication [79]. In pigs, these cells (Table 1) represent $0.1-0.3 \%$ of blood leukocytes and their role during PRRS was not clear until 2010 when few groups started to consider the involvement of these cells during the infection.

Zuckermann's group studied, for the first time, the exposure of pDC, much broadly defined as CD4hi CD172alow CD1a+ CD11a+ CD11b- CD11c- CD16+ CD18+ CD29+ CD44+ SLAII+, to several pig viruses and, among them, American PRRSV [80]. PRRSV-2 46448 was not able to induce the production of IFN $\alpha$ in pDCs, even when doses were 100-fold. PRRSV-2 was able to stimulate a low but detectable IL2 production, but it failed to induce detectable IL8, IFN $\gamma, \operatorname{TNF} \alpha$, IL12, and IRF7 production. PRRSV exposed pDC remained relatively inert, showing unaltered morphology and CD80/86 downregulation when compared with untreated cells [80]. Subsequently, the study was expanded with several PRRSV-2 strains that were used in combination with potent pDC stimulators as TGEV and ODN D19 [81]. Interestingly, prolonged incubation of porcine pDC with PRRSV-2 did not significantly alter cell viability and $\mathrm{pDC}$ were resistant to the infection. Additionally, $\mathrm{pDC}$ suppression occurred independent of virus viability and the acidification of pDC early endosomes, but correlated with diminished levels of IFN $\alpha$ mRNA. This change was attributed to an abrogation of transcription resulting from a decrease in IRF7 production, limited as a consequence of the nuclear translocation block of STAT1. PRRSV strains confirmed TNF $\alpha$ synthesis inhibition but promoted NFkB phosporilation, which is necessary for pro-inflammatory cytokines expression [81].

Zuckermann opened a new research direction in PRRSV that was subsequently taken over by the Summerfield group in the last five years. They started to explore interactions of both PRRSV genotypes with pDC using a broad spectrum of PRRSV-1 and 2 strains [82,83]. Controversially, Summerfield at al. demonstrated how several type 2 strains induced weak or no suppression of IFN $\alpha$ in CpG-stimulated pDC and stimulated IFN- $\alpha$ in CD172alow CD4hi CD14- pDC. Interestingly, a high percentage of pDC was observed after PRRSV stimulation when compared to mock, suggesting the promotion of $\mathrm{pDC}$ survival by the virus [82]. Additionally, in this study, PRRSV sensing by pDC did not require live virus and pDC were confirmed to not be permissive to PRRSV. IFN $\alpha$ response involved the activation of the TLR7 pathway and it was enhanced by IFN $\gamma$ and IL4. A surprising finding was that moDC were protected from PRRSV infection and killing when cultured with enriched pDC [82]. The divergent outcomes that were obtained by Zuckermann and Summerfield may lead back to the different pig genetics and to the diverse $\mathrm{pDC}$ isolation method and virus strains that were adopted in the studies. The role of pig genetics in the different outcomes after PRRSV infection has been reported [84-86], but its relationship with innate immune responses and particularly with pDC remains to be elucidated [87]. 
Data from both groups and genotypes found agreement only when pDC were exposed to Lena, the recent virulent PRRSV-1.3 strain that showed not to be able to induce IFN $\alpha$ in pDC in vitro but pig infected in vivo with Lena showed a systemic IFN $\alpha$ response [83]. In particular, an exosome fraction of Lena-infected cells but not Lena virions themselves were able to activate pDC [83].

PRRSV infected macrophages were more potent in activating pDC independently of the viral strains. This activation required cell adhesion molecules mediating contacts between $M \Phi$ and $\mathrm{pDC}$, intact cytoskeleton and sphingomyelinase activity, but it was not induced by free PRRSV virions released from infected macrophages. Additionally, ITGAL-mediated intercellular adhesion was required for efficient sensing of PRRSV-infected M $M$ [83].

Taken together, all of the findings demonstrate that pDC respond to PRRSV- 1 and 2 genotypes and suppressive activities are moderate and strain-dependent (Figure 1). They may be a source of IFN $\alpha$ responses reported in PRRSV-infected animals, further contributing to the puzzling immunopathogenesis of PRRS.

\subsection{Neutrophils}

Pigs that develop interstitial pneumonia in the lungs after PRRSV infection normally show the mononuclear infiltration of alveolar septae and accumulations with macrophages and cell debris in the alveoli. Generally, high pathogenic strains exhibited severe pathology with increased neutrophils, mast cells, and macrophages when compared with low virulent strains [75,88]. Additionally, PRRSV-2 (IAF-Klop) infection leads to a significant increase in proteolytic activity in pulmonary fluids. Maximal activity was found at 7 and 14 days pi, with a return towards normal levels at day 42 . Zymographic analyses showed a significant increase in the secretion of matrix metalloproteases 2 and 9 , which are two enzymes involved in tissue remodeling [89].

Neutrophils (PMNs) interact with opsonized immune complexes through Fc $\gamma$ receptors, activating and inhibitory receptors, which bind the Fc domain of IgG. In a study using PRRSV-2 HN07-1 or BJ-4, viral infection downregulates PMNs antibody-dependent phagocytosis and also impaired PMNs ability to kill E. coli, thus confirming that PMNs were impaired during PRRSV infection. In infected animals, the expression of Fc $\gamma$ RIIIA inhibitory receptor decreased and reached the lowest point at 5 dpi in both PRRSV strains, and together with the late upregulation of Fc $\gamma$ RIIIB, both contribute to decreased PMNs phagocytosis. The oxygen burst function of the PMNs was also depressed, and generally the consequences of infection by the more pathogenic strain HN07-1 were greater [90].

In another study, the PMNs infiltration was determined by the measurement of myeloperoxidase and enzyme activity in the lung, together with qPCR. In the lung, IL8, which is chemoattractant for neutrophil recruitment, was upregulated, and ICAM-1, responsible for firm neutrophils adhesion and transendothelial migration, was high in naturally infected animals. Moreover, VCAM-1 displayed a high level in experimentally and naturally infected pig lungs [91]. The induction of IL8 by PRRSV was further confirmed in vivo and in vitro, and it is likely through the TAK-1/JNK/AP-1 pathway [92].

In summary, PRRSV infection mainly impairs PMNs antibody-dependent phagocytosis and bacteria killing ability, together with the depression of the oxygen burst function, but seem to induce IL8 production (Figures 1 and 2).

\subsection{NK and $\gamma \delta$ Tcells}

It is surprising that very few works have studied NK and $\gamma \delta \mathrm{T}$ cells during PRRSV infection. One of the first preliminary studies was performed in Spain, where the piglets were inoculated with PRRSV-1 5710. T cell cultures that were established by stimulating responding cells with PRRSV showed an increase of double positive memory CD8+CD4+ as well as CD4-CD8+ effector lymphocyte subsets within activated cells, whereas CD4+CD8 - declined along the time. Within the activated cells, those expressing the TCR $\gamma \delta$ receptor also increased, with most of them also being positive for CD8. In resting cells, the majority of $\gamma \delta$ cells were CD8 - [93]. Almost concomitant, the Bianchi's group studied the change in detailed CD8+ cells subpopulations in BAL fluid in pigs that were infected 
with PRRSV-1 TerHuurne. NK (Table 1) were the main cells present in the lung of gnotobiotic and SPF piglets during the first days of infection, whereas CD8 $+\gamma \delta$ T cells presence was never relevant After day 7, the increase of CD8+ cells correlated with a rapid decrease of PRRSV in the BAL fluid and CD8 $+\gamma \delta \mathrm{T}$ cells disappeared in the CD8+ cells [94]. Nevertheless, the use of different European strains showed different patterns in BAL leucocyte populations at early and late time points. In fact, at day 3 pi a significantly higher percentage of CD8 $-\gamma \delta \mathrm{T}$ cells was observed in pigs that were infected with Belgium A and Lelystad, but not in strain Lena. At day 35 pi, cytotoxic T cells were almost double in percentage in all infections and CD8 $-\gamma \delta \mathrm{T}$ cells were significantly lower [95].

On the other side, in a Canadian study using a PRRSV-2 experimental infection (LHVA-93-3), Magar's group investigated the persistence of the virus in blood, spleen, lymph nodes, and tonsil. The authors discriminated between different CD8+ T cell subsets, and also between those NK cells. They defined NK cells as CD2+ CD8low and MIL4+, and they were not significantly modified in spleen and blood during infection in spite of a transient increase in the spleen at 3pi, followed by a gradual decrease up until 60 days pi. However, NK cells were rarely present in the tonsil and mediastinal lymph node, and they increased only at 3 days pi. Thus, it seemed that NK were not significantly modified during PRRSV-2 infection [96].

With the prototype VR-2332 in germ free piglets, the proportion $\gamma \delta \mathrm{T}$ cells and NK decreased in BAL and only the CD2+CD8a $+\gamma \delta \mathrm{T}$ subset increased. Tracheo-bronchial and mesenteric lymph nodes showed no differences in frequencies of NK and $\gamma \delta \mathrm{T}$, but the CD2+CD $8 \alpha+$ subset increased together with a proportional decrease in the CD2-CD8 $\alpha$ - subset [97].

An interesting study was performed in gilts, which were experimentally inoculated twice with PRRSV-2 MN-30100 and monitored for lymphocyte subpopulations, antigen specific proliferation, and IFN $\gamma$ production. Following primary exposure to PRRSV, peripheral circulating $\gamma \delta \mathrm{T}$ cells percentage increased from day 14 to day 70, and then decreased to control at 120 days. $\gamma \delta \mathrm{T}$ cells responded to PRRSV infection significantly when compared to CD4 at an early stage and they were the major producer of IFN $\gamma$ throughout the study [98]. Another study using different Minnesota strains, together with the prototype PRRSV-2 VR2332, showed an opposite outcome in tissues (PBMC, lung, tonsil, LN, bone marrow, spleen). PRRSV infection did not change the CD4+ or CD8+ population in any tissue, and by contrast, the $\gamma \delta$ T cells were significantly decreased in lung and all LN and reduced non-significantly in every other tissue [99].

Seven-week-old nursery pigs in a commercial setting were injected with MN 1-18-2, and at day 2 pi, approximately $50 \%$ of viremic pigs had greater than $50 \%$ reduction in NK cell mediated cytotoxicity. Reduced frequency of CD4-CD8+ and CD4+CD8+ T cells and upregulated frequency of lymphocytes bearing natural Treg phenotype was detected in viremic pigs. All of the viremic contact pigs also had comparable immune cell modulation [100].

More recently, the interaction between NK and PRRSV-infected PAM was investigated in vitro. NK cytotoxicity assay was performed while using enriched NK cells as effector cells and Lelystad PRRSV-1-infected PAM as target. NK cytotoxicity against PRRSV-infected PAM decreased, starting from 6 hpi till 12 hpi. UV inactivated PRRSV also suppressed NK activity, but much less than infectious PRRSV, and co-incubation with infected PAM inhibited the degranulation of NK cells. By using supernatant from infected PAM, data showed that the suppressive effect of PRRSV in NK cytotoxicity was not mediated by soluble factors [101]. Successively, Cao et al. still considered the involvement of NK and $\gamma \delta$ T cells during a vaccination study with a recombinant MLV vaccine that was incorporated with the porcine IL15 or IL18 gene fused to a signal that can anchor the cytokines to the cell membrane. In this case, immunization enhanced NK and $\gamma \delta \mathrm{T}$ cells responses and conferred improved protection against heterologous challenge (NADC20) [102].

Even with a limited number of studies, the data indicated that NK and $\gamma \delta \mathrm{T}$ cells interaction during PRRSV infection is altered with a suppressive effect on NK and the modulation of $\gamma \delta \mathrm{T}$ cells during the course of the infection. In particular, this is relevant when considering that $\gamma \delta \mathrm{T}$ cells are an important source of IFN $\gamma$ during PRRSV infection (Figures 1 and 2). 


\section{Innate Cellular Immune Responses Triggered by SwIV}

\subsection{Macrophages and Dendritic Cells}

It is worth mentioning some in vitro experiments by several groups that attempted to understand the interaction of these cells with SwIVs. Kim et al. (2009) showed the MФ culture supernatant from M $\Phi$ infected with SwIV H1N2. Significant differences in TNF $\alpha$ concentration between SwIV-infected and uninfected alveolar MФ were detected at different hpi, with a peak at 36 hpi. These results suggested that TNF $\alpha$ might be an important mediator in the pathophysiology of SwIV infection [103].

Another in vitro study used three-dimensional/four (3D/4) cells, a spontaneously transformed line of swine MФ (ATCC), infected with a pandemic H1N1 virus [104]. This report demonstrated that $\mathrm{A}(\mathrm{H} 1 \mathrm{~N} 1) \mathrm{pdm} / 2009$ retains the ability to infect and replicate in swine $\mathrm{M} \Phi$, inducing a typical cytopathic effect ( $16 \mathrm{~h} \mathrm{pi)} \mathrm{and} \mathrm{destroying} \mathrm{the} \mathrm{cell} \mathrm{monolayer} \mathrm{(} 32 \mathrm{~h} \mathrm{pi}$ ). This study also examined the pattern of cytokine responses in pH1N1-infected swine M $\Phi$ by real time RT-PCR. IL6 and IL8 levels were up regulated at $16 \mathrm{~h}$ and the level of IL8 continued to rise up at $36 \mathrm{hpi}$. The robust induction of antiviral IFN $\beta$ and TNF family members, which may be attributable to cell death, was also observed. FasL and TNF $\alpha$ remained undetectable, while the TNF-related apoptosis-inducing ligand (TRAIL) seemed to be the most abundant one before infection. FasL and TNF $\alpha$ were most robustly induced, but TRAIL was only mildly induced in response to infection. The level of IL1 $\beta$ remained unchanged throughout the infection (different from Barbe et al. [105]), indicating that IL6 and IL8, as well as TNF $\alpha$, were the main pro-inflammatory cytokines that were up-regulated. The authors also observed the induction of RIG-1 and MDA-5, which appeared to be completely suppressed by inhibitors of ERK1/2 or JNK1/2. This indicated that the induction of RIG-1 or MDA-5 depends on the activation of ERK1/2 and JNK1/2 in pig MФ [104].

For the first time, our group described the interaction between porcine bone marrow-derived DC (poBMDC) (cDC) and SwIV H3N2 in vitro. The infection of poBMDC resulted in a structure resembling IV inside vesicles and also free in the cytoplasm of the cells. Viral progeny was undetectable in the supernatant but limited replication was detected in the first $8 \mathrm{hpi}$. However, the viral particles from infected-poBMDC were only able to induce a cytopathic effect in susceptible cells when cell-to-cell interaction was favored [106]. Additionally, they observed that similarly to the SwIV H3N2, porcine DC also supported a limited replication of other IVs during the first $8 \mathrm{hpi}$, without release of infectious progeny [106]. Additionally, these viruses similarly modulated the expression of NFkB, TGF $\beta$ and IL10 genes. However, they induced different kinetics and levels of inflammatory cytokines. Infection of poBMDC with SwIV induced a peak of IFN $\alpha$ secretion at $24 \mathrm{hpi}$, whereas, with the others, the production of IFN $\alpha$ was not detected. SwIV and highly pathogenic avian influenza (HPAI) induced more TNF $\alpha$ when compared to huIV and low pathogenic avian influenza (LPAI). SwIV, LPAI, and HPAI induced an increase of IL12 from 16 to 24 hpi and all of the viruses used induced IL18 secretion in a time-dependent manner [107].

Summerfield's group also used GM-CSF derived DC infected with other avian and porcine IVs. They also generated recombinant reassortants by reverse genetics to elucidate the role of the single gene segments in the activation of $\mathrm{CDC}$. The highest IFN type I responses were achieved by porcine virus reassortants that contained the avian polymerase gene PB2. This finding was not due to the differential tropism, since all of the viruses infected GM-CSF derived DC equally (and also porcine PK-15 epithelial cells) and infectivity was independent of HA expressed by the virus. All of the viruses induced $\mathrm{MHCII}$, but porcine $\mathrm{H} 1 \mathrm{~N} 1$ expressing the avian viral PB2 more prominently induced nuclear NFkB translocation when compared to its parental strains. Therefore, in the case of porcine DC, PB2 was defined as an important viral element controlling IFN type I. While all the viruses had a comparable ability to infect DC, to initiate replication and to activate the cells in terms of MHCII induction, only those expressing PB2 derived from H5N1 were unable to prevent IFN type I induction; however, no viral progeny was detected [108]. 
When considering the distinct features of $\mathrm{pDC}$ and the crucial role of IFN in fighting virus infections, Bel at al. [109] analyzed the interactions of different influenza A viruses isolated from avian, human and swine with pDC obtained from pigs. Their results demonstrated that porcine pDC could produce high levels of IFN $\alpha$ in response to all of the tested strains, with subtype-specific differences in a virus-dose dependent manner. High levels of IFN $\alpha$ were detected upon live, chemically inactivated, or UV-inactivated virus stimulation. In contrast, heat-inactivated virus failed to induce a response. The observation that chemical and UV-inactivation did not abolish IFN $\alpha$ release indicated that non-infectious particles are also stimulatory for pDC. Additionally, these treatments did not abolish hemagglutination, suggesting that the integrity of HA and its binding function are necessary in inducing IFN $\alpha$ responses in pDC. At low viral doses, H5N1 and H7N1 avian viruses are more efficient in infecting pDC when compared to human H1N1 and at inducing the secretion of IFN $\alpha$ [109].

In vivo infection with SwIV mainly occurs in the respiratory-tract and the lungs of infected pigs, thus innate cells in the lungs are the first ones encountering the virus. One of the main components of the respiratory immune system is the $\mathrm{DC} / \mathrm{M} \Phi$ network that is involved in sensing foreign antigens, controlling inflammation, and initiating the adaptive immune responses. We have adapted a recently proposed nomenclature from Guilliams et al. [110] distinguishing between two levels of identification. The first level focuses on the origin of the cell-type progenitor (adult bone-marrow proDC for conventional DC ( $\mathrm{cDC}$ ), adult blood monocytes for monocyte-derived cells (moCells), or embryonic monocyte-derived precursors that were settled in peripheral tissues for

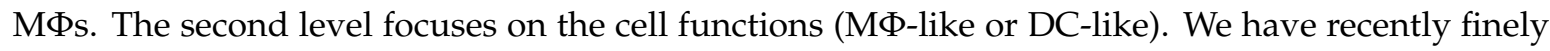
defined the phenotypes and functions of DC/MФ populations in the different compartments of the swine respiratory tract at a steady state and upon IAV infections in the pig [31]. We have defined

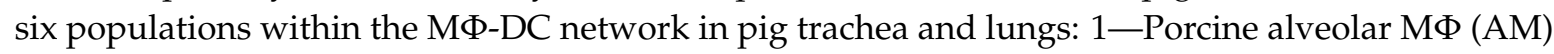
CD163hi/CD11b-likeneg and expressed high levels of MerTK and CD64; 2-AM-like population, the CD163hi 'interstitial' AM, unambiguously localized in the interstitium and representing $>50 \%$ of the SLAIIhi parenchymal cells; 3-A third M $\Phi$-like cell was described as SLAIIhi lung population: the CD163int cells. According to their M $\Phi$ features and their CCR2 and CX3CR1 expressions, they can be considered as moMФ; 4-inflammatory moDC CD163low; 5-cDC1, FLT3, CD172a- expressing XCR1; cDC2, CD163-/CD172a+/XCR1-/Langerin+. After the infection of pigs with two field isolates, the CD163low/moDC population was the only one that significantly increased in numbers after both swine (sw)H3N2 and swH1N2 infections. Sorted lung CD172a-/cDC1 produced more IL12A mRNA, the Th1 inducer cytokine, than CD163-/cDC1 and CD163low/moDC, both in mock and IAV-infected animals in agreement with their Th1-inducing capacities in allogeneic reactions. Neither IL13 nor IL4 transcripts, which are the Th2-inducing cytokines, were detected. Finally, no differences in IL6 transcription were observed between the three DC subsets, both at steady state and upon infections, which is in agreement with the absence of a specific allogenic Th17-inducing DC subset [31].

Recently, a study highlighted the role of the inflammasome activation within influenza virus infection, in which a 2009 pandemic H1N1 induced less IL1 $\beta$ than swine influenza viruses (SwIVs). Their in vitro studies revealed that the NS1 C terminus of pandemic H1N1, but not that of SwIV was able to significantly inhibit NLRP3 inflammasome-mediated IL1 $\beta$ production, revealing a new mechanism of innate immune evasion achieved by the NS1 protein in $\mathrm{pH} 1 \mathrm{~N} 1 / 09$ [111].

In summary, data showed that SwIV interacts with DC in vitro by inducing different kinetics and levels of inflammatory cytokines. Porcine pDC can produce high levels of IFN $\alpha$, with subtype-specific differences in a virus-dose dependent manner, with PB2 being an important control factor for IFN $\alpha$ secretion in $\mathrm{pDC}$. However, in vivo only CD163low/moDC population significantly increased in numbers after SwIV and lung CD172a-/CDC1 produced more IL12A mRNA than their counterparts, showing a distinctive activation pattern (Figures 2 and 3). 


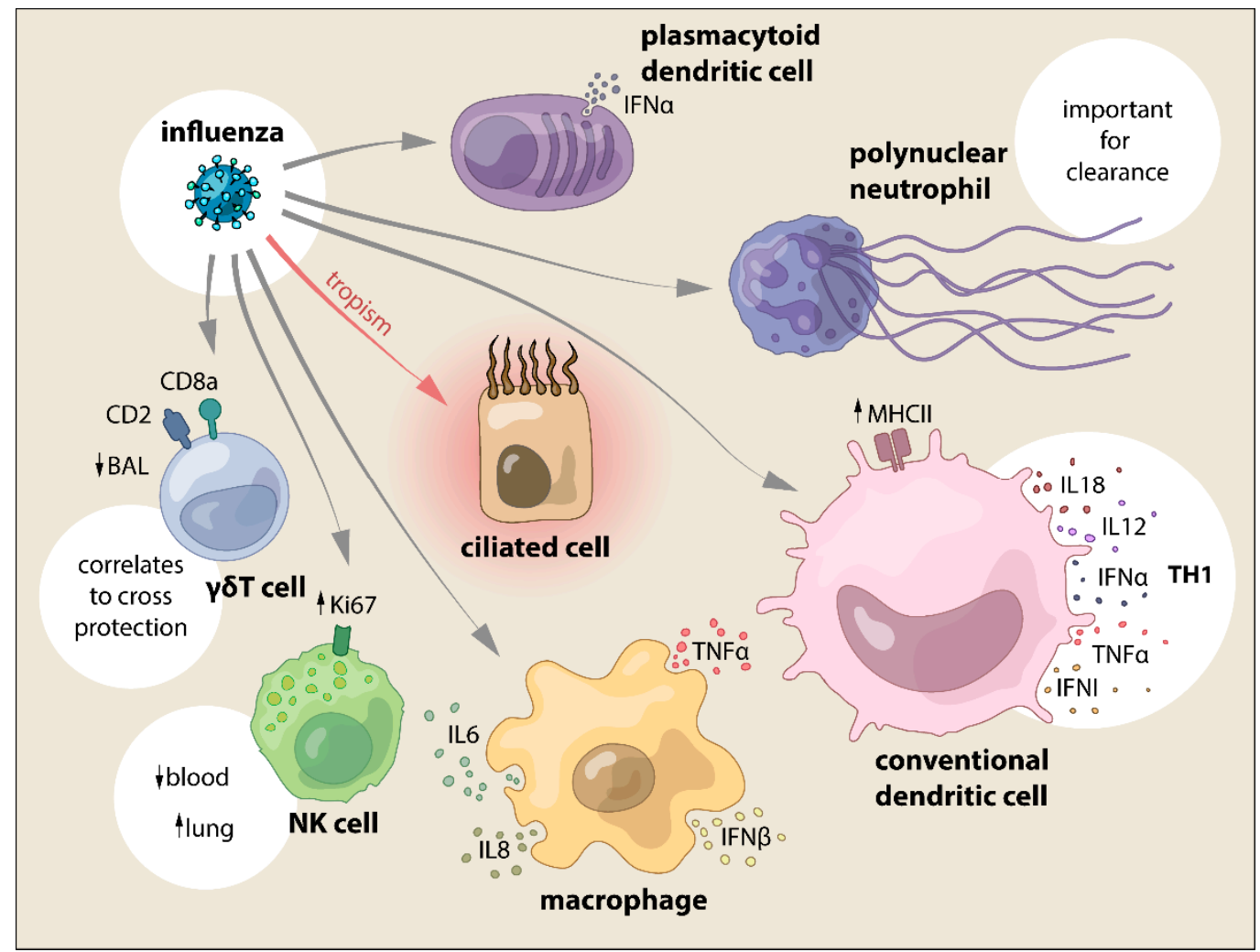

Figure 3. SwIV interaction with cells from the innate immune system and the main effects reported.

\subsection{Neutrophils}

Neutrophils are important host defense cells against influenza virus during the phase of innate immunity. Although the role of neutrophils against influenza virus infections has been debated, neutrophils have been shown to play a role in the control and clearance of the influenza virus in experimental models [112-115].

The results from the study from Kim et al. demonstrated SwIV nucleic acid that is present in neutrophils by in situ hybridization yet, it was not clear whether the SwIV virus could replicate in the porcine neutrophil although the human influenza virus can replicate in human neutrophils [116]. One important function of neutrophils is phagocytosis. Hence, the SwIV that was detected in the neutrophils may have resulted from uptake (Figure 3). Further study needs to determine whether SwIV can replicate in porcine neutrophils and their role in influenza infection in the pig, as the role of neutrophils in SwIV infection is far from understood (Figures 2 and 3).

\subsection{NK and $\gamma \delta T$}

Upon binding to the influenza virus, HA, the receptors trigger the NK cells to lyse the infected cell [117]. It has been suggested that invariant NKT (iNKT) cells stimulate the induction of cellular immunity and regulate infection-induced pathology [118]. With the identification of specific NK cell markers in pigs [42], some studies regarding the role of these cells in influenza infected pigs have been addressed. However, there are still few reports on the role of NK cells in swine during influenza virus infection.

Recently, it was demonstrated that NKp46+ lymphocytes accumulate in the vicinity of influenza A-infected cells in the lung of infected pigs. NKp46+NKcells are recruited from the blood to infected parts of the lungs in swine that were inoculated with the 2009 pandemic influenza virus at the same time as a decline in NKp46+ NK cells was demonstrated in the blood of infected pigs. Moreover, influenza virus does not infect the NKp46+ cells in the lungs and they do not undergo apoptosis [119]. 
Another study investigated the possibility that, besides NKp46+ NK cells, CD3+NKp46+ cells might also be involved in influenza infection. Thus, this lymphocyte population was analyzed in animals that were experimentally infected with the 2009 pandemic H1N1 influenza virus strain. A significant decrease in the total number of CD3+NKp46+ lymphocytes in PBMC could be observed in infected animals $1 \mathrm{dpi}$ when compared with control animals. Furthermore, a significant increase in the frequency of CD3+NKp46+ lymphocytes could be detected in the lungs of infected animals as compared with the control group on day 3 pi. When compared with analyses from day $1 \mathrm{pi}$, a significant increase in proliferation by Ki67+ cells could be detected within CD3+NKp46+ cells in the lungs on day 3 pi [43]. Although anti-NKp46 mAb has been used to define NK during SwIV studies, the same approach has not been considered during PRRSV infection studies.

Likewise, few studies have been performed on the role of porcine $\gamma \delta \mathrm{T}$ cells during swine influenza infection. It has been shown that this subset increases in the lung following infection with H1N1 virus [120], in particular, the levels of $\gamma \delta \mathrm{T}$ cells were significantly higher in BAL and lower in tonsils of infected pigs when compared with control. Conversely, in another previous work, the $\gamma \delta \mathrm{T}$ cells percentage in the lung remained unchanged during H3N2 and H1N1 infections [121], showing a marked discrepancy in the results.

During a vaccination study, the level of $\gamma \delta \mathrm{T}$ cells was considered in cross-protection. A reverse genetics-derived H3N2 SwIV with truncated NS1 and wild type viruses were used to evaluate T cell priming and cross-protective efficacy against heterosubtypic H1N1 challenge. In control animals that were challenged with $\mathrm{H} 1 \mathrm{~N} 1$, there were no changes in the $\gamma \delta \mathrm{T}$ populations along the experiment, whereas immunization induces antigen-specific $\gamma \delta \mathrm{T}$ cells, including IFN $\gamma$ and IL10 recall responses, before and after heterologous challenge. The group with the most robust $\gamma \delta \mathrm{T}$ cell responses correlated with the greatest cross-protection, suggesting that these cells may have had a protective role during the infection [122].

Finally, in a comparative study with PRRSV infection, using H1N1 SwIV in germ free piglets, the different subpopulation of NK and $\gamma \delta \mathrm{T}$ cells were evaluated. In the BAL of infected pigs, a decrease in the proportion of $\gamma \delta \mathrm{T}$ cells or NK cells was shown. The CD2+CD8a- $\gamma \delta \mathrm{T}$ subset was comparable to control animals, whereas $C D 2+C D 8 a+\gamma \delta \mathrm{T}$ increased, and CD2-CD8a- $-\gamma \delta \mathrm{T}$ subset was lower than the control. In the tracheobronchial draining lymph node, there were no differences in the frequencies of NK and $\gamma \delta$ T, but the distributions of the CD2+CD8 $\alpha$ - subset increased. Similarly, the mesenteric lymph node analysis of $\gamma \delta$ T cell subpopulations revealed no significant change in the proportion of any subset [97].

The few studies on the role of NK and $\gamma \delta \mathrm{T}$ cells during SwIV infections show that they may have a relevant function during infection and clearance, yet their interaction is far from understood (Figures 2 and 3).

\section{Innate Immune Responses Triggered by SwIV and PRRSV Co-Infection}

While considering PRRSV and influenza virus co-infection, it is important to point out that both of the viruses have a different cell tropism, with macrophages being the main target of PRRSV and respiratory epithelial cells the main target of SwIV. Taking into account these premises, very few studies considered PRRSV-SwIV co-infection at the molecular level in the experimental set up, although both of the viruses are relevant contributors during PRDC and lung infections [1,123,124], and their presence is frequently observed during serological studies under field conditions [4].

Epidemiological studies have been performed to construct statistical models to evaluate a significant association between PRRSV and SwIV or other co-infectious agents, and to assess the effects of changes in age and management system on coinfection status, serological profiles, lung lesions, and histological lesions. One study was performed in piglets with different ages and logistic regression models were used to assess the co-infection. Clinically ill PRRSV-positive pigs were more likely than PRRSV-negative pigs to be co-infected with SwIV and to have lung scores that were in the 11 to $50 \%$ range. Nine and 16-week old pigs were 15.57 and 5.75 times as likely to be co-infected with 
SwIV, respectively [125]. Similarly, a statistically important association between pre-weaning infection with SwIV and PRRSV and post-weaning mortality was detected, with the season and number of days on feed also being associated [126]. US seroprevalence of PRRSV and SwIV co-infection in finisher herds was also estimated by the USDA NAHMS swine 2000 national study, with $4.9 \%$ herds serologically positive and 5.9\% finishers (regardless the vaccination status) [127].

Early studies during the 1990s were mainly related to clinical and histopathological findings, where the inflammation of the bronchiolar wall was more pronounced in PRRSV/SwIV infected pigs than PRRSV, bronchiolar and lung lymph nodes were larger in the co-infection than in SwIV alone, but, at the end the PRRSV infection did not aggravate the acute stage of SwIV [128], or SwIV was only slightly affected by prior PRRSV [129].

Only in the last five years, Meurens' group has been the one primarily investigating the interaction between SwIV and PRRSV in an experimental in vitro system. The first study was performed in porcine alveolar macrophages (PAM) and precision cut lung slices (PCLS) from eight-week-old pigs. They used the PRRSV-2 VR-2385 and SwIV Canadian strain H1N1 applied simultaneously or $3 \mathrm{~h}$ apart on PAM and PCLS for $18 \mathrm{~h}$. Interference that was caused by the first virus on replication of the second was observed and a synergic effect between PRRSV and SwIV was observed for some transcripts, such as TLR3, RIG1, and IFN $\beta$ in PCLS. PRRSV infection $3 \mathrm{~h}$ prior SwIV reduced the response to SwIV, while the SwIV infection prior to PRRSV infection had limited impact [130]. The second recent study was performed in a trachea epithelial cell line expressing CD163 (NPTr-CD163), which is the main receptor for PRRSV. The cell line was receptive to both viruses and was used to assess the interference between the two. SwIV and PRRSV interacted differently with the modified cell line, but they were interfering each other in terms of replication when infected in the same cell with consequence on the antiviral response (LGP2, MDA5, TLR8, IFN $\alpha$, IFN $\beta$, IFN $\lambda 1$, MX2, OAS, PKR) [131].

More studies are required to precisely define the interaction of both viruses on the immune system and the consequences for disease and vaccination.

\section{Conclusions}

Given the importance of the innate immune system during the first critical hours and days of exposure to a new pathogen, it is surprising to realize how scattered the information is when speaking about two of the main players in PRDC. PRRSV interaction with M $\Phi$ and DC has been studied in some detail, but there are controversial data between different groups. For SwIV, the picture seems more in agreement, but the whole picture of fine-tuning mechanisms of virus interaction with the host innate immune is still far from complete. The modulation of NK, PMN, or $\gamma \delta \mathrm{T}$ cells, in general, has not received as much attention as their APC counterparts and there are numerous gaps in the knowledge regarding the role of these cells in both virus infections and their interaction between them. Finally, studies on the co-infection of PRRSV-SwIV have received little attention within the scientific community, and even epidemiological studies have shown significant association between PRRSV and SwIV. Studies in these directions will pave the way to understand PRDC in better detail and possible design strategies to combat this disease.

Funding: This research was funded by CSIC. Check carefully that the details given are accurate and use the standard spelling of funding agency names at https:/ / search.crossref.org/funding, any errors may affect your future funding.

Acknowledgments: The authors thank Rada Ellegård for Figures 1-3 and Kyle Miskell for editing English language.

Conflicts of Interest: The authors declare that the research was conducted in the absence of any commercial or financial relationships that could be construed as a potential conflict of interest.

\section{References}

1. Opriessnig, T.; Gimenez-Lirola, L.G.; Halbur, P.G. Polymicrobial respiratory disease in pigs. Anim. Health Res. Rev. 2011, 12, 133-148. [CrossRef] [PubMed] 
2. Susan, L.; Brockmeier, P.G.H.; Thacker, E.L. Porcine Respiratory Disease Complex. In Polymicrobial Diseases; Brogden, K.A., Guthmiller, J.M., Eds.; ASM Press: Washington, DC, USA, 2002. [CrossRef]

3. Thacker, E.L. Immunology of the porcine respiratory disease complex. Vet. Clin. N. Am. Food Anim. Pract. 2001, 17, 551-565. [CrossRef]

4. Fraile, L.; Alegre, A.; Lopez-Jimenez, R.; Nofrarias, M.; Segales, J. Risk factors associated with pleuritis and cranio-ventral pulmonary consolidation in slaughter-aged pigs. Vet. J. 2010, 184, 326-333. [CrossRef] [PubMed]

5. Sassu, E.L.; Bosse, J.T.; Tobias, T.J.; Gottschalk, M.; Langford, P.R.; Hennig-Pauka, I. Update on Actinobacillus pleuropneumoniae-knowledge, gaps and challenges. Transbound. Emerg. Dis. 2018, 65 (Suppl. 1), 72-90. [CrossRef] [PubMed]

6. Zimmerman, J.J. Diseases of Swine, 10th ed.; Locke, A., Karriker, J.Z., Alejandro, R., Kent, S., Gregory, S., Eds.; Wiley-Blackwell: Chichester, West Sussex, UK, 2012.

7. Qin, S.; Ruan, W.; Yue, H.; Tang, C.; Zhou, K.; Zhang, B. Viral communities associated with porcine respiratory disease complex in intensive commercial farms in Sichuan province, China. Sci. Rep. 2018, 8, 13341. [CrossRef] [PubMed]

8. Yassin, A.F.; Hupfer, H.; Siering, C.; Schumann, P. Comparative chemotaxonomic and phylogenetic studies on the genus Arcanobacterium Collins et al. 1982 emend. Lehnen et al. 2006: Proposal for Trueperella gen. nov. and emended description of the genus Arcanobacterium. Int. J. Syst. Evol. Microbiol. 2011, 61, 1265-1274. [CrossRef] [PubMed]

9. Butler, J.E.; Lager, K.M.; Golde, W.; Faaberg, K.S.; Sinkora, M.; Loving, C.; Zhang, Y.I. Porcine reproductive and respiratory syndrome (PRRS): An immune dysregulatory pandemic. Immunol. Res. 2014, 59, 81-108. [CrossRef] [PubMed]

10. Lunney, J.K.; Fang, Y.; Ladinig, A.; Chen, N.; Li, Y.; Rowland, B.; Renukaradhya, G.J. Porcine Reproductive and Respiratory Syndrome Virus (PRRSV): Pathogenesis and Interaction with the Immune System. Annu. Rev. Anim. Biosci. 2016, 4, 129-154. [CrossRef] [PubMed]

11. Kappes, M.A.; Faaberg, K.S. PRRSV structure, replication and recombination: Origin of phenotype and genotype diversity. Virology 2015, 479-480, 475-486. [CrossRef] [PubMed]

12. Kuhn, J.H.; Lauck, M.; Bailey, A.L.; Shchetinin, A.M.; Vishnevskaya, T.V.; Bao, Y.; Ng, T.F.; LeBreton, M.; Schneider, B.S.; Gillis, A.; et al. Reorganization and expansion of the nidoviral family Arteriviridae. Arch. Virol. 2016, 161, 755-768. [CrossRef] [PubMed]

13. Duan, X.; Nauwynck, H.J.; Pensaert, M.B. Effects of origin and state of differentiation and activation of monocytes/macrophages on their susceptibility to porcine reproductive and respiratory syndrome virus (PRRSV). Arch. Virol. 1997, 142, 2483-2497. [CrossRef] [PubMed]

14. Bordet, E.; Maisonnasse, P.; Renson, P.; Bouguyon, E.; Crisci, E.; Tiret, M.; Descamps, D.; Bernelin-Cottet, C.; Urien, C.; Lefevre, F.; et al. Porcine Alveolar Macrophage-like cells are pro-inflammatory Pulmonary Intravascular Macrophages that produce large titers of Porcine Reproductive and Respiratory Syndrome Virus. Sci. Rep. 2018, 8, 10172. [CrossRef] [PubMed]

15. Zhang, Q.; Yoo, D. PRRS virus receptors and their role for pathogenesis. Vet. Microbiol. 2015, 177, $229-241$. [CrossRef] [PubMed]

16. Burkard, C.; Lillico, S.G.; Reid, E.; Jackson, B.; Mileham, A.J.; Ait-Ali, T.; Whitelaw, C.B.; Archibald, A.L. Precision engineering for PRRSV resistance in pigs: Macrophages from genome edited pigs lacking CD163 SRCR5 domain are fully resistant to both PRRSV genotypes while maintaining biological function. PLoS Pathog. 2017, 13, e1006206. [CrossRef] [PubMed]

17. Whitworth, K.M.; Rowland, R.R.; Ewen, C.L.; Trible, B.R.; Kerrigan, M.A.; Cino-Ozuna, A.G.; Samuel, M.S.; Lightner, J.E.; McLaren, D.G.; Mileham, A.J.; et al. Gene-edited pigs are protected from porcine reproductive and respiratory syndrome virus. Nat. Biotechnol. 2016, 34, 20-22. [CrossRef] [PubMed]

18. Krammer, F.; Smith, G.J.D.; Fouchier, R.A.M.; Peiris, M.; Kedzierska, K.; Doherty, P.C.; Palese, P.; Shaw, M.L.; Treanor, J.; Webster, R.G.; et al. Influenza. Nat. Rev. Dis. Primers 2018, 4, 4. [CrossRef] [PubMed]

19. Tong, S.; Zhu, X.; Li, Y.; Shi, M.; Zhang, J.; Bourgeois, M.; Yang, H.; Chen, X.; Recuenco, S.; Gomez, J.; et al. New world bats harbor diverse influenza A viruses. PLoS Pathog. 2013, 9, e1003657. [CrossRef] [PubMed]

20. Medina, R.A.; Garcia-Sastre, A. Influenza A viruses: New research developments. Nat. Rev. Microbiol. 2011, 9, 590-603. [CrossRef] [PubMed] 
21. Webster, R.G.; Bean, W.J.; Gorman, O.T.; Chambers, T.M.; Kawaoka, Y. Evolution and ecology of influenza A viruses. Microbiol. Rev. 1992, 56, 152-179. [PubMed]

22. Vincent, A.; Awada, L.; Brown, I.; Chen, H.; Claes, F.; Dauphin, G.; Donis, R.; Culhane, M.; Hamilton, K.; Lewis, N.; et al. Review of influenza A virus in swine worldwide: A call for increased surveillance and research. Zoonoses Public Health 2014, 61, 4-17. [CrossRef] [PubMed]

23. Bourret, V. Avian influenza viruses in pigs: An overview. Vet. J. 2018, 239, 7-14. [CrossRef] [PubMed]

24. Solorzano, A.; Foni, E.; Cordoba, L.; Baratelli, M.; Razzuoli, E.; Bilato, D.; Martin del Burgo, M.A.; Perlin, D.S.; Martinez, J.; Martinez-Orellana, P.; et al. Cross-Species Infectivity of H3N8 Influenza Virus in an Experimental Infection in Swine. J. Virol. 2015, 89, 11190-11202. [CrossRef] [PubMed]

25. Kahn, R.E.; Ma, W.; Richt, J.A. Swine and influenza: A challenge to one health research. Curr. Top. Microbiol. Immunol. 2014, 385, 205-218. [CrossRef] [PubMed]

26. Crisci, E.; Mussa, T.; Fraile, L.; Montoya, M. Review: Influenza virus in pigs. Mol. Immunol. 2013, 55, $200-211$. [CrossRef] [PubMed]

27. Mair, K.H.; Sedlak, C.; Kaser, T.; Pasternak, A.; Levast, B.; Gerner, W.; Saalmuller, A.; Summerfield, A.; Gerdts, V.; Wilson, H.L.; et al. The porcine innate immune system: An update. Dev. Comp. Immunol. 2014, 45, 321-343. [CrossRef] [PubMed]

28. Summerfield, A.; McCullough, K.C. The porcine dendritic cell family. Dev. Comp. Immunol. 2009, 33, $299-309$. [CrossRef] [PubMed]

29. Carrasco, C.P.; Rigden, R.C.; Schaffner, R.; Gerber, H.; Neuhaus, V.; Inumaru, S.; Takamatsu, H.; Bertoni, G.; McCullough, K.C.; Summerfield, A. Porcine dendritic cells generated in vitro: Morphological, phenotypic and functional properties. Immunology 2001, 104, 175-184. [CrossRef] [PubMed]

30. Edwards, J.C.; Everett, H.E.; Pedrera, M.; Mokhtar, H.; Marchi, E.; Soldevila, F.; Kaveh, D.A.; Hogarth, P.J.; Johns, H.L.; Nunez-Garcia, J.; et al. CD1(-) and CD1(+) porcine blood dendritic cells are enriched for the orthologues of the two major mammalian conventional subsets. Sci. Rep. 2017, 7, 40942. [CrossRef] [PubMed]

31. Maisonnasse, P.; Bouguyon, E.; Piton, G.; Ezquerra, A.; Urien, C.; Deloizy, C.; Bourge, M.; Leplat, J.J.; Simon, G.; Chevalier, C.; et al. The respiratory DC/macrophage network at steady-state and upon influenza infection in the swine biomedical model. Mucosal Immunol. 2016, 9, 835-849. [CrossRef] [PubMed]

32. Ezquerra, A.; Revilla, C.; Alvarez, B.; Perez, C.; Alonso, F.; Dominguez, J. Porcine myelomonocytic markers and cell populations. Dev. Comp. Immunol. 2009, 33, 284-298. [CrossRef] [PubMed]

33. Arora, S.; Dev, K.; Agarwal, B.; Das, P.; Syed, M.A. Macrophages: Their role, activation and polarization in pulmonary diseases. Immunobiology 2018, 223, 383-396. [CrossRef] [PubMed]

34. Sang, Y.; Rowland, R.R.; Blecha, F. Interaction between innate immunity and porcine reproductive and respiratory syndrome virus. Anim. Health Res. Rev. 2011, 12, 149-167. [CrossRef] [PubMed]

35. Sica, A.; Mantovani, A. Macrophage plasticity and polarization: In vivo veritas. J. Clin. Investig. 2012, 122, 787-795. [CrossRef] [PubMed]

36. Liegeois, M.; Legrand, C.; Desmet, C.J.; Marichal, T.; Bureau, F. The interstitial macrophage: A long-neglected piece in the puzzle of lung immunity. Cell. Immunol. 2018, 330, 91-96. [CrossRef] [PubMed]

37. Thanawongnuwech, R.; Halbur, P.G.; Thacker, E.L. The role of pulmonary intravascular macrophages in porcine reproductive and respiratory syndrome virus infection. Anim. Health Res. Rev. 2000, 1, 95-102. [CrossRef] [PubMed]

38. Brea, D.; Meurens, F.; Dubois, A.V.; Gaillard, J.; Chevaleyre, C.; Jourdan, M.L.; Winter, N.; Arbeille, B.; Si-Tahar, M.; Gauthier, F.; et al. The pig as a model for investigating the role of neutrophil serine proteases in human inflammatory lung diseases. Biochem. J. 2012, 447, 363-370. [CrossRef] [PubMed]

39. Denyer, M.S.; Wileman, T.E.; Stirling, C.M.; Zuber, B.; Takamatsu, H.H. Perforin expression can define CD8 positive lymphocyte subsets in pigs allowing phenotypic and functional analysis of natural killer, cytotoxic T, natural killer T and MHC un-restricted cytotoxic T-cells. Vet. Immunol. Immunopathol. 2006, 110, 279-292. [CrossRef] [PubMed]

40. Takamatsu, H.H.; Denyer, M.S.; Stirling, C.; Cox, S.; Aggarwal, N.; Dash, P.; Wileman, T.E.; Barnett, P.V. Porcine gammadelta $\mathrm{T}$ cells: Possible roles on the innate and adaptive immune responses following virus infection. Vet. Immunol. Immunopathol. 2006, 112, 49-61. [CrossRef] [PubMed]

41. Gerner, W.; Kaser, T.; Saalmuller, A. Porcine T lymphocytes and NK cells-An update. Dev. Comp. Immunol. 2009, 33, 310-320. [CrossRef] [PubMed] 
42. Mair, K.H.; Essler, S.E.; Patzl, M.; Storset, A.K.; Saalmuller, A.; Gerner, W. NKp46 expression discriminates porcine NK cells with different functional properties. Eur. J. Immunol. 2012, 42, 1261-1271. [CrossRef] [PubMed]

43. Mair, K.H.; Stadler, M.; Talker, S.C.; Forberg, H.; Storset, A.K.; Mullebner, A.; Duvigneau, J.C.; Hammer, S.E.; Saalmuller, A.; Gerner, W. Porcine CD3(+)NKp46(+) Lymphocytes Have NK-Cell Characteristics and Are Present in Increased Frequencies in the Lungs of Influenza-Infected Animals. Front. Immunol. 2016, 7, 263. [CrossRef] [PubMed]

44. Stepanova, K.; Sinkora, M. The expression of CD25, CD11b, SWC1, SWC7, MHC-II, and family of CD45 molecules can be used to characterize different stages of gammadelta T lymphocytes in pigs. Dev. Comp. Immunol. 2012, 36, 728-740. [CrossRef] [PubMed]

45. Stepanova, K.; Sinkora, M. Porcine gammadelta T lymphocytes can be categorized into two functionally and developmentally distinct subsets according to expression of CD2 and level of TCR. J. Immunol. 2013, 190, 2111-2120. [CrossRef] [PubMed]

46. Holtkamp, D.J.; Kliebenstein, J.B.; Neumann, E.J. Assessment of the economic impact of porcine reproductive and respiratory syndrome virus on United States pork producers. J. Swine Health Prod. 2013, 21, 72-84.

47. Loving, C.L.; Osorio, F.A.; Murtaugh, M.P.; Zuckermann, F.A. Innate and adaptive immunity against Porcine Reproductive and Respiratory Syndrome Virus. Vet. Immunol. Immunopathol. 2015, 167, 1-14. [CrossRef] [PubMed]

48. Bordet, E.; Blanc, F.; Tiret, M.; Crisci, E.; Bouguyon, E.; Renson, P.; Maisonnasse, P.; Bourge, M.; Leplat, J.J.; Giuffra, E.; et al. Porcine Reproductive and Respiratory Syndrome Virus Type 1.3 Lena Triggers Conventional Dendritic Cells 1 Activation and T Helper 1 Immune Response Without Infecting Dendritic Cells. Front. Immunol. 2018, 9, 2299. [CrossRef] [PubMed]

49. Darwich, L.; Diaz, I.; Mateu, E. Certainties, doubts and hypotheses in porcine reproductive and respiratory syndrome virus immunobiology. Virus Res. 2010, 154, 123-132. [CrossRef] [PubMed]

50. Wang, L.; Hu, S.; Liu, Q.; Li, Y.; Xu, L.; Zhang, Z.; Cai, X.; He, X. Porcine alveolar macrophage polarization is involved in inhibition of porcine reproductive and respiratory syndrome virus (PRRSV) replication. J. Vet. Med. Sci. 2017, 79, 1906-1915. [CrossRef] [PubMed]

51. Jiang, Z.; Zhou, X.; Michal, J.J.; Wu, X.L.; Zhang, L.; Zhang, M.; Ding, B.; Liu, B.; Manoranjan, V.S.; Neill, J.D.; et al. Reactomes of porcine alveolar macrophages infected with porcine reproductive and respiratory syndrome virus. PLoS ONE 2013, 8, e59229. [CrossRef] [PubMed]

52. Zeng, N.; Wang, C.; Liu, S.; Miao, Q.; Zhou, L.; Ge, X.; Han, J.; Guo, X.; Yang, H. Transcriptome Analysis Reveals Dynamic Gene Expression Profiles in Porcine Alveolar Macrophages in Response to the Chinese Highly Pathogenic Porcine Reproductive and Respiratory Syndrome Virus. BioMed Res. Int. 2018, 2018, 1538127. [CrossRef] [PubMed]

53. Wang, L.; Zhou, L.; Hu, D.; Ge, X.; Guo, X.; Yang, H. Porcine reproductive and respiratory syndrome virus suppresses post-transcriptionally the protein expression of IFN-beta by upregulating cellular microRNAs in porcine alveolar macrophages in vitro. Exp. Ther. Med. 2018, 15, 115-126. [CrossRef] [PubMed]

54. Zhang, J.; Sun, P.; Gan, L.; Bai, W.; Wang, Z.; Li, D.; Cao, Y.; Fu, Y.; Li, P.; Bai, X.; et al. Genome-wide analysis of long noncoding RNA profiling in PRRSV-infected PAM cells by RNA sequencing. Sci. Rep. 2017, 7, 4952. [CrossRef] [PubMed]

55. Wang, C.; Shi, X.; Zhang, X.; Wang, A.; Wang, L.; Chen, J.; Deng, R.; Zhang, G. The Endoribonuclease Activity Essential for the Nonstructural Protein 11 of Porcine Reproductive and Respiratory Syndrome Virus to Inhibit NLRP3 Inflammasome-Mediated IL-1beta Induction. DNA Cell Biol. 2015, 34, 728-735. [CrossRef] [PubMed]

56. Bi, J.; Song, S.; Fang, L.; Wang, D.; Jing, H.; Gao, L.; Cai, Y.; Luo, R.; Chen, H.; Xiao, S. Porcine reproductive and respiratory syndrome virus induces IL-1beta production depending on TLR4/MyD88 pathway and NLRP3 inflammasome in primary porcine alveolar macrophages. Mediat. Inflamm. 2014, 2014, 403515. [CrossRef] [PubMed]

57. Liang, W.; Ji, L.; Zhang, Y.; Zhen, Y.; Zhang, Q.; Xu, X.; Liu, B. Transcriptome Differences in Porcine Alveolar Macrophages from Tongcheng and Large White Pigs in Response to Highly Pathogenic Porcine Reproductive and Respiratory Syndrome Virus (PRRSV) Infection. Int. J. Mol. Sci. 2017, 18, 1475. [CrossRef] [PubMed] 
58. Charerntantanakul, W.; Platt, R.; Roth, J.A. Effects of porcine reproductive and respiratory syndrome virus-infected antigen-presenting cells on $\mathrm{T}$ cell activation and antiviral cytokine production. Viral Immunol. 2006, 19, 646-661. [CrossRef] [PubMed]

59. Flores-Mendoza, L.; Silva-Campa, E.; Resendiz, M.; Osorio, F.A.; Hernandez, J. Porcine reproductive and respiratory syndrome virus infects mature porcine dendritic cells and up-regulates interleukin-10 production. Clin. Vaccine Immunol. 2008, 15, 720-725. [CrossRef] [PubMed]

60. Loving, C.L.; Brockmeier, S.L.; Sacco, R.E. Differential type I interferon activation and susceptibility of dendritic cell populations to porcine arterivirus. Immunology 2007, 120, 217-229. [CrossRef] [PubMed]

61. Pineyro, P.E.; Subramaniam, S.; Kenney, S.P.; Heffron, C.L.; Gimenez-Lirola, L.G.; Meng, X.J. Modulation of Proinflammatory Cytokines in Monocyte-Derived Dendritic Cells by Porcine Reproductive and Respiratory Syndrome Virus Through Interaction with the Porcine Intercellular-Adhesion-Molecule-3-Grabbing Nonintegrin. Viral Immunol. 2016, 29, 546-556. [CrossRef] [PubMed]

62. Rodriguez-Gomez, I.M.; Kaser, T.; Gomez-Laguna, J.; Lamp, B.; Sinn, L.; Rumenapf, T.; Carrasco, L.; Saalmuller, A.; Gerner, W. PRRSV-infected monocyte-derived dendritic cells express high levels of SLA-DR and CD80/86 but do not stimulate PRRSV-naive regulatory T cells to proliferate. Vet. Res. 2015, 46, 54. [CrossRef] [PubMed]

63. Silva-Campa, E.; Cordoba, L.; Fraile, L.; Flores-Mendoza, L.; Montoya, M.; Hernandez, J. European genotype of porcine reproductive and respiratory syndrome (PRRV) infects monocyte-derived dendritic cells but does not induce Treg cells. Virology 2010, 396, 264-271. [CrossRef] [PubMed]

64. Singleton, H.; Graham, S.P.; Bodman-Smith, K.B.; Frossard, J.P.; Steinbach, F. Establishing Porcine Monocyte-Derived Macrophage and Dendritic Cell Systems for Studying the Interaction with PRRSV-1. Front. Microbiol. 2016, 7, 832. [CrossRef] [PubMed]

65. Liu, J.; Wei, S.; Liu, L.; Shan, F.; Zhao, Y.; Shen, G. The role of porcine reproductive and respiratory syndrome virus infection in immune phenotype and Th1/Th2 balance of dendritic cells. Dev. Comp. Immunol. 2016, 65, 245-252. [CrossRef] [PubMed]

66. Proll, M.J.; Neuhoff, C.; Schellander, K.; Uddin, M.J.; Cinar, M.U.; Sahadevan, S.; Qu, X.; Islam, M.A.; Poirier, M.; Muller, M.A.; et al. Transcriptome profile of lung dendritic cells after in vitro porcine reproductive and respiratory syndrome virus (PRRSV) infection. PLoS ONE 2017, 12, e0187735. [CrossRef] [PubMed]

67. Resendiz, M.; Valenzuela, O.; Hernandez, J. Response of the cDC1 and cDC2 subtypes of tracheal dendritic cells to porcine reproductive and respiratory syndrome virus. Vet. Microbiol. 2018, 223, 27-33. [CrossRef] [PubMed]

68. Wang, X.; Eaton, M.; Mayer, M.; Li, H.; He, D.; Nelson, E.; Christopher-Hennings, J. Porcine reproductive and respiratory syndrome virus productively infects monocyte-derived dendritic cells and compromises their antigen-presenting ability. Arch. Virol. 2007, 152, 289-303. [CrossRef] [PubMed]

69. Park, J.Y.; Kim, H.S.; Seo, S.H. Characterization of interaction between porcine reproductive and respiratory syndrome virus and porcine dendritic cells. J. Microbiol. Biotechnol. 2008, 18, 1709-1716. [PubMed]

70. Chen, X.; Bai, J.; Liu, X.; Song, Z.; Zhang, Q.; Wang, X.; Jiang, P. Nsp1alpha of Porcine Reproductive and Respiratory Syndrome Virus Strain BB0907 Impairs the Function of Monocyte-Derived Dendritic Cells via the Release of Soluble CD83. J. Virol. 2018, 92, e00366-18. [CrossRef] [PubMed]

71. Chen, X.; Zhang, Q.; Bai, J.; Zhao, Y.; Wang, X.; Wang, H.; Jiang, P. The Nucleocapsid Protein and Nonstructural Protein 10 of Highly Pathogenic Porcine Reproductive and Respiratory Syndrome Virus Enhance CD83 Production via NF-kappaB and Sp1 Signaling Pathways. J. Virol. 2017, 91, e00986-17. [CrossRef] [PubMed]

72. Zhang, H.; Guo, X.; Nelson, E.; Christopher-Hennings, J.; Wang, X. Porcine reproductive and respiratory syndrome virus activates the transcription of interferon alpha/beta (IFN-alpha/beta) in monocyte-derived dendritic cells (Mo-DC). Vet. Microbiol. 2012, 159, 494-498. [CrossRef] [PubMed]

73. Silva-Campa, E.; Flores-Mendoza, L.; Resendiz, M.; Pinelli-Saavedra, A.; Mata-Haro, V.; Mwangi, W.; Hernandez, J. Induction of T helper 3 regulatory cells by dendritic cells infected with porcine reproductive and respiratory syndrome virus. Virology 2009, 387, 373-379. [CrossRef] [PubMed]

74. Gimeno, M.; Darwich, L.; Diaz, I.; de la Torre, E.; Pujols, J.; Martin, M.; Inumaru, S.; Cano, E.; Domingo, M.; Montoya, M.; et al. Cytokine profiles and phenotype regulation of antigen presenting cells by genotype-I porcine reproductive and respiratory syndrome virus isolates. Vet. Res. 2011, 42, 9. [CrossRef] [PubMed] 
75. Weesendorp, E.; Stockhofe-Zurwieden, N.; Popma-De Graaf, D.J.; Fijten, H.; Rebel, J.M. Phenotypic modulation and cytokine profiles of antigen presenting cells by European subtype 1 and 3 porcine reproductive and respiratory syndrome virus strains in vitro and in vivo. Vet. Microbiol. 2013, 167, 638-650. [CrossRef] [PubMed]

76. Li, Y.L.; Darwich, L.; Mateu, E. Characterization of the attachment and infection by Porcine reproductive and respiratory syndrome virus 1 isolates in bone marrow-derived dendritic cells. Vet. Microbiol. 2018, 223, 181-188. [CrossRef] [PubMed]

77. Doeschl-Wilson, A.; Wilson, A.; Nielsen, J.; Nauwynck, H.; Archibald, A.; Ait-Ali, T. Combining laboratory and mathematical models to infer mechanisms underlying kinetic changes in macrophage susceptibility to an RNA virus. BMC Syst. Biol. 2016, 10, 101. [CrossRef] [PubMed]

78. Frydas, I.S.; Verbeeck, M.; Cao, J.; Nauwynck, H.J. Replication characteristics of porcine reproductive and respiratory syndrome virus (PRRSV) European subtype 1 (Lelystad) and subtype 3 (Lena) strains in nasal mucosa and cells of the monocytic lineage: Indications for the use of new receptors of PRRSV (Lena). Vet. Res. 2013, 44, 73. [CrossRef] [PubMed]

79. Colonna, M.; Trinchieri, G.; Liu, Y.J. Plasmacytoid dendritic cells in immunity. Nat. Immunol. 2004, 5, 1219-1226. [CrossRef] [PubMed]

80. Calzada-Nova, G.; Schnitzlein, W.; Husmann, R.; Zuckermann, F.A. Characterization of the cytokine and maturation responses of pure populations of porcine plasmacytoid dendritic cells to porcine viruses and toll-like receptor agonists. Vet. Immunol. Immunopathol. 2010, 135, 20-33. [CrossRef] [PubMed]

81. Calzada-Nova, G.; Schnitzlein, W.M.; Husmann, R.J.; Zuckermann, F.A. North American porcine reproductive and respiratory syndrome viruses inhibit type I interferon production by plasmacytoid dendritic cells. J. Virol. 2011, 85, 2703-2713. [CrossRef] [PubMed]

82. Baumann, A.; Mateu, E.; Murtaugh, M.P.; Summerfield, A. Impact of genotype 1 and 2 of porcine reproductive and respiratory syndrome viruses on interferon-alpha responses by plasmacytoid dendritic cells. Vet. Res. 2013, 44, 33. [CrossRef] [PubMed]

83. Garcia-Nicolas, O.; Auray, G.; Sautter, C.A.; Rappe, J.C.; McCullough, K.C.; Ruggli, N.; Summerfield, A. Sensing of Porcine Reproductive and Respiratory Syndrome Virus-Infected Macrophages by Plasmacytoid Dendritic Cells. Front. Microbiol. 2016, 7, 771. [CrossRef] [PubMed]

84. Abella, G.; Pena, R.N.; Nogareda, C.; Armengol, R.; Vidal, A.; Moradell, L.; Tarancon, V.; Novell, E.; Estany, J.; Fraile, L. A WUR SNP is associated with European Porcine Reproductive and Respiratory Virus Syndrome resistance and growth performance in pigs. Res. Vet. Sci. 2016, 104, 117-122. [CrossRef] [PubMed]

85. Dekkers, J.; Rowland, R.R.R.; Lunney, J.K.; Plastow, G. Host genetics of response to porcine reproductive and respiratory syndrome in nursery pigs. Vet. Microbiol. 2017, 209, 107-113. [CrossRef] [PubMed]

86. Koltes, J.E.; Fritz-Waters, E.; Eisley, C.J.; Choi, I.; Bao, H.; Kommadath, A.; Serao, N.V.; Boddicker, N.J.; Abrams, S.M.; Schroyen, M.; et al. Identification of a putative quantitative trait nucleotide in guanylate binding protein 5 for host response to PRRS virus infection. BMC Genomics 2015, 16, 412. [CrossRef] [PubMed]

87. Reiner, G. Genetic resistance-An alternative for controlling PRRS? Porcine Health Manag. 2016, 2, 27. [CrossRef] [PubMed]

88. Han, D.; Hu, Y.; Li, L.; Tian, H.; Chen, Z.; Wang, L.; Ma, H.; Yang, H.; Teng, K. Highly pathogenic porcine reproductive and respiratory syndrome virus infection results in acute lung injury of the infected pigs. Vet. Microbiol. 2014, 169, 135-146. [CrossRef] [PubMed]

89. Girard, M.; Cleroux, P.; Tremblay, P.; Dea, S.; St-Pierre, Y. Increased proteolytic activity and matrix metalloprotease expression in lungs during infection by porcine reproductive and respiratory syndrome virus. J. Gen. Virol. 2001, 82, 1253-1261. [CrossRef] [PubMed]

90. Wan, B.; Qiao, S.; Li, P.; Jin, Q.; Liu, Y.; Bao, D.; Liu, M.; Wang, Y.; Zhang, G. Impairment of the antibody-dependent phagocytic function of PMNs through regulation of the FcgammaRs expression after porcine reproductive and respiratory syndrome virus infection. PLoS ONE 2013, 8, e66965. [CrossRef] [PubMed]

91. Liu, J.; Hou, M.; Yan, M.; Lu, X.; Gu, W.; Zhang, S.; Gao, J.; Liu, B.; Wu, X.; Liu, G. ICAM-1-dependent and ICAM-1-independent neutrophil lung infiltration by porcine reproductive and respiratory syndrome virus infection. Am. J. Physiol. Lung Cell. Mol. Physiol. 2015, 309, L226-L236. [CrossRef] [PubMed] 
92. Liu, Y.; Du, Y.; Wang, H.; Du, L.; Feng, W.H. Porcine reproductive and respiratory syndrome virus (PRRSV) up-regulates IL-8 expression through TAK-1/JNK/AP-1 pathways. Virology 2017, 506, 64-72. [CrossRef] [PubMed]

93. Lopez Fuertes, L.; Domenech, N.; Alvarez, B.; Ezquerra, A.; Dominguez, J.; Castro, J.M.; Alonso, F. Analysis of cellular immune response in pigs recovered from porcine respiratory and reproductive syndrome infection. Virus Res. 1999, 64, 33-42. [CrossRef]

94. Samsom, J.N.; de Bruin, T.G.; Voermans, J.J.; Meulenberg, J.J.; Pol, J.M.; Bianchi, A.T. Changes of leukocyte phenotype and function in the broncho-alveolar lavage fluid of pigs infected with porcine reproductive and respiratory syndrome virus: A role for CD8(+) cells. J. Gen. Virol. 2000, 81, 497-505. [CrossRef] [PubMed]

95. Weesendorp, E.; Rebel, J.M.; Popma-De Graaf, D.J.; Fijten, H.P.; Stockhofe-Zurwieden, N. Lung pathogenicity of European genotype 3 strain porcine reproductive and respiratory syndrome virus (PRRSV) differs from that of subtype 1 strains. Vet. Microbiol. 2014, 174, 127-138. [CrossRef] [PubMed]

96. Lamontagne, L.; Page, C.; Larochelle, R.; Magar, R. Porcine reproductive and respiratory syndrome virus persistence in blood, spleen, lymph nodes, and tonsils of experimentally infected pigs depends on the level of CD8high T cells. Viral Immunol. 2003, 16, 395-406. [CrossRef] [PubMed]

97. Sinkora, M.; Butler, J.E.; Lager, K.M.; Potockova, H.; Sinkorova, J. The comparative profile of lymphoid cells and the T and B cell spectratype of germ-free piglets infected with viruses SIV, PRRSV or PCV2. Vet. Res. 2014, 45, 91. [CrossRef] [PubMed]

98. Olin, M.R.; Batista, L.; Xiao, Z.; Dee, S.A.; Murtaugh, M.P.; Pijoan, C.C.; Molitor, T.W. Gammadelta lymphocyte response to porcine reproductive and respiratory syndrome virus. Viral Immunol. 2005, 18, 490-499. [CrossRef] [PubMed]

99. Xiao, Z.; Batista, L.; Dee, S.; Halbur, P.; Murtaugh, M.P. The level of virus-specific T-cell and macrophage recruitment in porcine reproductive and respiratory syndrome virus infection in pigs is independent of virus load. J. Virol. 2004, 78, 5923-5933. [CrossRef] [PubMed]

100. Dwivedi, V.; Manickam, C.; Binjawadagi, B.; Linhares, D.; Murtaugh, M.P.; Renukaradhya, G.J. Evaluation of immune responses to porcine reproductive and respiratory syndrome virus in pigs during early stage of infection under farm conditions. Virol. J. 2012, 9, 45. [CrossRef] [PubMed]

101. Cao, J.; Grauwet, K.; Vermeulen, B.; Devriendt, B.; Jiang, P.; Favoreel, H.; Nauwynck, H. Suppression of NK cell-mediated cytotoxicity against PRRSV-infected porcine alveolar macrophages in vitro. Vet. Microbiol. 2013, 164, 261-269. [CrossRef] [PubMed]

102. Cao, Q.M.; Ni, Y.Y.; Cao, D.; Tian, D.; Yugo, D.M.; Heffron, C.L.; Overend, C.; Subramaniam, S.; Rogers, A.J.; Catanzaro, N.; et al. Recombinant Porcine Reproductive and Respiratory Syndrome Virus Expressing Membrane-Bound Interleukin-15 as an Immunomodulatory Adjuvant Enhances NK and gammadelta T Cell Responses and Confers Heterologous Protection. J. Virol. 2018, 92. [CrossRef] [PubMed]

103. Kim, B.; Ahn, K.K.; Ha, Y.; Lee, Y.H.; Kim, D.; Lim, J.H.; Kim, S.H.; Kim, M.Y.; Cho, K.D.; Lee, B.H.; et al. Association of tumor necrosis factor-alpha with fever and pulmonary lesion score in pigs experimentally infected with swine influenza virus subtype H1N2. J. Vet. Med. Sci. 2009, 71, 611-616. [CrossRef] [PubMed]

104. Gao, W.; Sun, W.; Qu, B.; Cardona, C.J.; Powell, K.; Wegner, M.; Shi, Y.; Xing, Z. Distinct regulation of host responses by ERK and JNK MAP kinases in swine macrophages infected with pandemic (H1N1) 2009 influenza virus. PLoS ONE 2012, 7, e30328. [CrossRef] [PubMed]

105. Barbe, F.; Atanasova, K.; Van Reeth, K. Cytokines and acute phase proteins associated with acute swine influenza infection in pigs. Vet. J. 2011, 187, 48-53. [CrossRef] [PubMed]

106. Mussa, T.; Rodriguez-Carino, C.; Pujol, M.; Cordoba, L.; Busquets, N.; Crisci, E.; Dominguez, J.; Fraile, L.; Montoya, M. Interaction of porcine conventional dendritic cells with swine influenza virus. Virology 2011, 420, 125-134. [CrossRef] [PubMed]

107. Mussa, T.; Ballester, M.; Silva-Campa, E.; Baratelli, M.; Busquets, N.; Lecours, M.P.; Dominguez, J.; Amadori, M.; Fraile, L.; Hernandez, J.; et al. Swine, human or avian influenza viruses differentially activates porcine dendritic cells cytokine profile. Vet. Immunol. Immunopathol. 2013, 154, 25-35. [CrossRef] [PubMed]

108. Ocana-Macchi, M.; Ricklin, M.E.; Python, S.; Monika, G.A.; Stech, J.; Stech, O.; Summerfield, A. Avian influenza A virus PB2 promotes interferon type I inducing properties of a swine strain in porcine dendritic cells. Virology 2012, 427, 1-9. [CrossRef] [PubMed] 
109. Bel, M.; Ocana-Macchi, M.; Liniger, M.; McCullough, K.C.; Matrosovich, M.; Summerfield, A. Efficient sensing of avian influenza viruses by porcine plasmacytoid dendritic cells. Viruses 2011, 3, 312-330. [CrossRef] [PubMed]

110. Guilliams, M.; Ginhoux, F.; Jakubzick, C.; Naik, S.H.; Onai, N.; Schraml, B.U.; Segura, E.; Tussiwand, R.; Yona, S. Dendritic cells, monocytes and macrophages: A unified nomenclature based on ontogeny. Nat. Rev. Immunol. 2014, 14, 571-578. [CrossRef] [PubMed]

111. Park, H.S.; Liu, G.; Thulasi Raman, S.N.; Landreth, S.L.; Liu, Q.; Zhou, Y. NS1 Protein of 2009 Pandemic Influenza A Virus Inhibits Porcine NLRP3 Inflammasome-Mediated Interleukin-1 Beta Production by Suppressing ASC Ubiquitination. J. Virol. 2018, 92, e00022-18. [CrossRef] [PubMed]

112. Fujisawa, H. Neutrophils play an essential role in cooperation with antibody in both protection against and recovery from pulmonary infection with influenza virus in mice. J. Virol. 2008, 82, 2772-2783. [CrossRef] [PubMed]

113. Salvatore, M.; Garcia-Sastre, A.; Ruchala, P.; Lehrer, R.I.; Chang, T.; Klotman, M.E. alpha-Defensin inhibits influenza virus replication by cell-mediated mechanism(s). J. Infect. Dis. 2007, 196, 835-843. [CrossRef] [PubMed]

114. Tate, M.D.; Ioannidis, L.J.; Croker, B.; Brown, L.E.; Brooks, A.G.; Reading, P.C. The role of neutrophils during mild and severe influenza virus infections of mice. PLoS ONE 2011, 6, e17618. [CrossRef] [PubMed]

115. Tripathi, S.; White, M.R.; Hartshorn, K.L. The amazing innate immune response to influenza A virus infection. Innate Immun. 2015, 21, 73-98. [CrossRef] [PubMed]

116. Zhao, Y.; Lu, M.; Lau, L.T.; Lu, J.; Gao, Z.; Liu, J.; Yu, A.C.; Cao, Q.; Ye, J.; McNutt, M.A.; et al. Neutrophils may be a vehicle for viral replication and dissemination in human H5N1 avian influenza. Clin. Infect. Dis. 2008, 47, 1575-1578. [CrossRef] [PubMed]

117. Mandelboim, O.; Lieberman, N.; Lev, M.; Paul, L.; Arnon, T.I.; Bushkin, Y.; Davis, D.M.; Strominger, J.L.; Yewdell, J.W.; Porgador, A. Recognition of haemagglutinins on virus-infected cells by NKp46 activates lysis by human NK cells. Nature 2001, 409, 1055-1060. [CrossRef] [PubMed]

118. Paget, C.; Ivanov, S.; Fontaine, J.; Blanc, F.; Pichavant, M.; Renneson, J.; Bialecki, E.; Pothlichet, J.; Vendeville, C.; Barba-Spaeth, G.; et al. Potential role of invariant NKT cells in the control of pulmonary inflammation and CD8+ T cell response during acute influenza A virus H3N2 pneumonia. J. Immunol. 2011, 186, 5590-5602. [CrossRef] [PubMed]

119. Forberg, H.; Hauge, A.G.; Valheim, M.; Garcon, F.; Nunez, A.; Gerner, W.; Mair, K.H.; Graham, S.P.; Brookes, S.M.; Storset, A.K. Early responses of natural killer cells in pigs experimentally infected with 2009 pandemic H1N1 influenza A virus. PLoS ONE 2014, 9, e100619. [CrossRef] [PubMed]

120. Khatri, M.; Dwivedi, V.; Krakowka, S.; Manickam, C.; Ali, A.; Wang, L.; Qin, Z.; Renukaradhya, G.J.; Lee, C.W. Swine influenza H1N1 virus induces acute inflammatory immune responses in pig lungs: A potential animal model for human H1N1 influenza virus. J. Virol. 2010, 84, 11210-11218. [CrossRef] [PubMed]

121. Heinen, P.P.; de Boer-Luijtze, E.A.; Bianchi, A.T. Respiratory and systemic humoral and cellular immune responses of pigs to a heterosubtypic influenza A virus infection. J. Gen. Virol. 2001, 82, 2697-2707. [CrossRef] [PubMed]

122. Kappes, M.A.; Sandbulte, M.R.; Platt, R.; Wang, C.; Lager, K.M.; Henningson, J.N.; Lorusso, A.; Vincent, A.L.; Loving, C.L.; Roth, J.A.; et al. Vaccination with NS1-truncated H3N2 swine influenza virus primes T cells and confers cross-protection against an H1N1 heterosubtypic challenge in pigs. Vaccine 2012, 30, 280-288. [CrossRef] [PubMed]

123. Choi, Y.K.; Goyal, S.M.; Joo, H.S. Retrospective analysis of etiologic agents associated with respiratory diseases in pigs. Can. Vet. J. 2003, 44, 735-737. [PubMed]

124. Fablet, C.; Marois-Crehan, C.; Simon, G.; Grasland, B.; Jestin, A.; Kobisch, M.; Madec, F.; Rose, N. Infectious agents associated with respiratory diseases in 125 farrow-to-finish pig herds: A cross-sectional study. Vet. Microbiol. 2012, 157, 152-163. [CrossRef] [PubMed]

125. A Dorr, P.M.; Gebreyes, W.A.; Almond, G.W. Porcine reproductive and respiratory syndrome virus: Age and management system disease modeling for pathogenic co-infection. J. Swine Health Prod. 2007, 15, 258-264.

126. Alvarez, J.; Sarradell, J.; Kerkaert, B.; Bandyopadhyay, D.; Torremorell, M.; Morrison, R.; Perez, A. Association of the presence of influenza A virus and porcine reproductive and respiratory syndrome virus in sow farms with post-weaning mortality. Prev. Vet. Med. 2015, 121, 240-245. [CrossRef] [PubMed] 
127. Bush, E.J.; Thacker, E.L.; Swenson, S.L. National Seroprevalence of PRRS, Mycoplasma and Swine Influenza Virus; American Association Of Swine Veterinarians: Iowa, IA, USA, 2003.

128. Pol, J.M.; van Leengoed, L.A.; Stockhofe, N.; Kok, G.; Wensvoort, G. Dual infections of PRRSV/influenza or PRRSV/Actinobacillus pleuropneumoniae in the respiratory tract. Vet. Microbiol. 1997, 55, 259-264. [CrossRef]

129. Van Reeth, K.; Nauwynck, H.; Pensaert, M. Dual infections of feeder pigs with porcine reproductive and respiratory syndrome virus followed by porcine respiratory coronavirus or swine influenza virus: A clinical and virological study. Vet. Microbiol. 1996, 48, 325-335. [CrossRef]

130. Dobrescu, I.; Levast, B.; Lai, K.; Delgado-Ortega, M.; Walker, S.; Banman, S.; Townsend, H.; Simon, G.; Zhou, Y.; Gerdts, V.; et al. In vitro and ex vivo analyses of co-infections with swine influenza and porcine reproductive and respiratory syndrome viruses. Vet. Microbiol. 2014, 169, 18-32. [CrossRef] [PubMed]

131. Provost, C.; Hamonic, G.; Gagnon, C.A.; Meurens, F. Dual infections of CD163 expressing NPTr epithelial cells with influenza A virus and PRRSV. Vet. Microbiol. 2017, 207, 143-148. [CrossRef] [PubMed]

(C) 2019 by the authors. Licensee MDPI, Basel, Switzerland. This article is an open access article distributed under the terms and conditions of the Creative Commons Attribution (CC BY) license (http://creativecommons.org/licenses/by/4.0/). 